Revista de Estudios Histórico-Jurídicos

[Sección historia del pensamiento político]

XLI (Valparaíso, Chile, 2019)

[pp. 437 - 465 ]

\title{
El Corpus politicum de San Pío X: una interpretación ANTIMODERNA
}

[The Corpus politicum of St. Pius X: an anti-modern interpretation]

\author{
Julio Alvear Téllez* \\ Universidad del Desarrollo, Santiago, Chile
}

\begin{abstract}
RESUMEN
En las últimas décadas, el corpus politicum de San Pío X ha sido objeto de diversas lecturas. En este trabajo se vuelve a la postura originaria: la que inserta el corpus politicum pianum dentro de la amplia mirada antimoderna del pontífice, envés de su designio positivo de Instaurare omnia in Christo. Para tales efectos, se revisan las líneas fundamentales de la bibliografía existente y se expone el núcleo de la doctrina política del papa Sarto sin intermediaciones, a partir de las fuentes directas, desde la clave de interpretación elegida. Los principios del corpus politicum pianum mantienen, en lo sustancial, su vigencia.
\end{abstract}

\section{Palabras Clave}

San Pío X - modernidad - modernismo - laicismo - democracia.

\section{ABSTRACT}

In recent decades, the corpus politicum of Saint Pius X has been the subject of various readings. In this work we return to the original position: the one that inserts the corpus politicum pianum within the broad anti-modern view of the pontiff, the reverse of his positive design of Instaurare omnia in Christo. For such effects, the fundamental lines of the existing bibliography are reviewed and the core of the political doctrine of Pope Sarto without intermediaries is exposed, starting from the direct sources, from the key of interpretation chosen. The principles of the corpus politicum pianum maintain, in substance, its validity.

\section{KEYWORDS}

St. Pius X - Modernity - Modernism - secularism - democracy.

RECIBIDO el 30 de abril de 2019 y ACEPTADO el 7 de julio de 2019

* Doctor en Derecho y Doctor en Filosofía, Universidad Complutense de Madrid. Profesor titular de la Facultad de Derecho de la Universidad del Desarrollo. Correo: jalvear@udd.cl 


\section{SAN Pío X: LAS Diversas INTERPRETACiONES}

La valoración del pontificado de San Pío X no depende sólo de su magisterio. Hay que mirar, asimismo, al conjunto de situaciones históricas que le encuadran y contextualizan.

Empero, el presente trabajo no puede hacerse cargo de este aspecto. Su objetivo es estudiar la doctrina del papa Sarto en sí misma considerada, y dentro de ésta, específicamente su corpus politicum. Haremos referencia a situaciones históricas puntuales cada vez que sea oportuno y lo permita la metodología y extensión del estudio. Para la evaluación histórica global de este pontificado remitimos a la aquilatada bibliografía que ha intentado conjugar y equilibrar sus distintas dimensiones (personales, doctrinales, diplomáticas, culturales, etc.) ${ }^{1}$.

También podría complementarse esta investigación con los presupuestos teológicos que dan sentido unitario a la orientación del pontificado. Sobre todo de teología de la historia. Los hay en este trabajo, pero a modo implícito. En sí misma no es una materia que nos corresponda ${ }^{2}$.

Ingresemos, entonces, de lleno, a nuestro objeto de estudio.

El Corpus politicum de San Pío X (Giuseppe Sarto, 1903-1914) ha sido objeto de diversas lecturas. En los “Cuadernos de la cárcel”, Gramsci destaca cómo el papa Sarto, en continuidad con sus predecesores, se dirige contra el "pensamiento moderno" y sus manifestaciones "filosóficas y políticas" 3 .

Es oportuno traer a colación la opinión de Gramsci pues revela cómo, en su época, el pontificado de San Pío X era percibido por uno de los filósofos más analíticos de la modernidad. En su opinión, la encíclica Pascendi incide en el

${ }^{1}$ Con diversos énfasis, para una valoración histórica del pontificado de San Pío X en su posicionamiento frente al mundo moderno, JEDIN, Hubert (dir.), Manual de historia de la Iglesia (Barcelona, Herder, 1978), VIII, pp. 531-726; Rops, Daniel, Historia de la Iglesia de Cristo (Madrid-Alcalá, Círculo de Amigos de la Historia, 1971), XII/1, pp. 159-217; MontalBán, Francisco; LlorCa, Bernardino y GarCía Villoslada, Ricardo, Historia de la Iglesia católica (2a ed., Madrid, Biblioteca de Autores Cristianos, 1958), IV, particularmente pp. 443-449 y 741-746.

${ }^{2}$ El Pontificado de San Pío X se vuelve incomprensible desde la llamada "teología de la secularización". Sobre esta última, IlLANES, José Luis, Cristianismo, historia, mundo (Pamplona, Eunsa, 1973), pp. 19-46 y 57-100. Lo mismo puede decirse de teologías contemporáneas, como la de Kasper, para quien "la teología sólo es posible en la corriente abierta del tiempo". KASPER, Walter, Situación y tareas actuales de la teología sistemática, en Él Mismo, Teología e Iglesia (Barcelona, Herder, 1989), p. 13. El tema merecería un estudio específico.

${ }^{3}$ Para el filósofo italiano, las "tres encíclicas orgánicas contra el pensamiento moderno" son la Mirari vos de Gregorio XVI, la Quanta Cura (con el Syllabus) de Pío IX y la Pascendi de San Pío X. Gramsci, Antonio, Cuadernos de la Cárcel (ed. crítica del Instituto Gramsci, a cargo de Valentino Guerratana, México, Ediciones Era, 1999), V, p. 114. El m o d e r n i s m o no es solo r e 1 i g i o s o, también s o c i a 1 . A Pascendi hay que sumar la condena a Le Sillon. Gramsci, Cuadernos, esta nota (2000), VI, p. 19. Incluso en una materia aparentemente inocua como la comunión temprana de los niños establecida por el decreto Quam singulari (8 de agosto de 2010), el filósofo italiano nota un sentido de oposición al espíritu moderno. Gramsci, Cuadernos, esta nota (1981), II, p. 289. 
modernismo, no porque el pensamiento moderno se redujera al solo aspecto religioso, sino, al contrario, porque amenazaba extenderse al interior de la Iglesia ${ }^{4}$.

El filósofo italiano supo captar la esencia del fenómeno. El modernismo no es solo un conjunto de doctrinas que aflora en el campo exegético con sus correlatos en el ámbito dogmático, sino un movimiento muchísimo más amplio que partiendo de determinados principios filosóficos -los propios del "pensamiento moderno"- deriva consecuencias políticas, sociales y jurídicas, con su proyección operativa al mundo de los hechos.

A este respecto, hay diversos equívocos a la hora de interpretar la línea antimodernista de San Pío X. Nombres insignes como Daniel Rops reducen el fenómeno a un asunto puramente exegético, ya superado5. Con las mejores intenciones, Rivière o Dal-Gal petrifican el modernismo a las manifestaciones teológicas de principios del siglo XX, y, como tal, le consideran un "incident clos". Autores como Bedeschi niegan abiertamente sus implicancias políticas ${ }^{7}$.

Pero Lamentabili o Pascendi no pueden ser separadas de los documentos propiamente políticos ni de las reformas pastorales, institucionales o jurídicas del papa Sarto. La lucha contra el modernismo es el envés del "Instaurare omnia in Christo" y constituye un solo continuo en sus diversas manifestaciones ${ }^{8}$. Así lo sugiere el mismo pontífice en su última alocución, cuando en la línea de Gregorio XVI, Pío IX y León XIII, aborda el peligro universal de la "conciliazione della Fede con lo spirito moderno"'.

Su sucesor inmediato, Benedicto XV, al reiterar la condena al modernismo, destaca no solo la necesidad de precaverse de sus e r r o r e $s$, sino también de sus t e n d e n c i a s y de su e s pír i t u, capaz de infectar los distintos ámbitos de la actividad humana ${ }^{10}$. Pío XI insiste no solo en el "modernismo teológico", sino

${ }^{4}$ Gramsci, Cuadernos, cit. (n. 3), V, p. 114.

${ }^{5}$ Daniel-Rops, L'église des Revolutions. Un combat pour Dieu (Paris, Fayard, 1963), p. 374.

${ }^{6}$ Rivière, Jean, voz Modernisme, en Vacant, Alfred; Mangenot, Eugene y Amann, Emile (dir.), Dictionnaire de théologie catholique (Paris, Librairie Letouzey, 1929), X/2, col.1041 y 2045; Dal-Gal, Geronimo, San Pio X. El papa santo (Madrid, Palabra, 1954), p. 136.

${ }^{7}$ BedesCHI, Lorenzo, Il modernismo italiano. Voci e volti (Cinisello Balsamo-Milano, Edizioni San Paolo, 1995), pp. 23-25.

${ }^{8}$ Ayuso, Miguel, La devastación modernista y su denuncia profética, en Verbo, 455-456 (Madrid, 2007), pp. 449-469; Castellano, Danilo, El modernismo politico-social, en Verbo, 455-456 (Madrid, 2007), pp. 422-430; Madiran, Jean, San Pio X, en Verbo, 529-539 (Madrid, 2014), pp. 731-756; Madiran, Jean, En el centenario de Notre charge apostolique, en Verbo, 491-492 (Madrid, 2011), pp. 15-25. Sobre los significados del Instaurare omnia in Christo, Cano, Luis, Instaurare omnia in Christo. La propuesta de San Pio X, en Saranyana, Josep et al., El caminar histórico de la santidad cristiana (Pamplona, Eunsa, 2003), pp. 325-338, con una distinción discutible (en su aplicación) entre lo perenne y lo superado. Sobre la vigencia del Instaurare en Benedicto XV, Pío XI y Pío XII, GonZÁlez-Quevedo Montfort s.j., Jesús, Por la instauración de un orden cristiano, en Verbo, pp. 959-980.

${ }^{9}$ Pío X, San, Alocución Il grave dolore, 28 de mayo de 1914, en AAS., 6 (Ciudad del Vaticano, 1914), p. 260.

${ }^{10}$ Benedicto XV, Encíclica “Ad Beatissimi Apostolorum”, 1 de noviembre de 1914, original 
también en el "modernismo moral, jurídico y social", no "menos condenable" que el primero ${ }^{11}$. Pío XII en los discursos de beatificación y canonización de Pío $\mathrm{X}$, destaca cómo el papa Sarto en sus diversas iniciativas enfrenta "la catástrofe espiritual del mundo moderno", el "espíritu sectario del siglo", en la línea de un fenómeno universal que obsta a la restauración de todas las cosas en Cristo ${ }^{12}$.

Después del Concilio Vaticano II se ha desarrollado una línea de abierta incomprensión respecto de las condenas al modernismo, sea en su vertiente religiosa, sea en su dimensión político-social. San Pío X habría encabezado un pontificado obstructor, que no supo discernir las tendencias positivas de la modernidad en aquellos ámbitos. De ahí su ojeriza hacia la crítica científica, su insistencia en restaurar la sociedad pre-revolucionaria, su rechazo a la democracia y a las libertades modernas ${ }^{13}$. Se ha llegado a decir que las condenas del papa Sarto carecen de validez, pues los principios liberales que antes se rechazaban hoy se aceptan, fruto de la profundización de los conceptos de persona, tolerancia y libertad ${ }^{14}$.

Abundan, asimismo, los intentos de componer una suerte de historia al revés, en donde los modernistas son los auténticos cristianos y el papa Sarto el gran victimario ${ }^{15}$. Se olvidan fácilmente las tácticas del movimiento modernista a la época del pontífice, así como los textos comprometedores de sus representantes más conspicuos ${ }^{16}$. Por otra parte, no hay que descuidar la animadversión

latino en $A A S$., 6 (Ciudad del Vaticano, 1914), pp. 565-581. Utilizamos la numeración de la versión digital de la Librería Editrice Vaticana, 25.

${ }^{11}$ Pío XI, Encíclica "Ubi Arcano", 23 de diciembre de 1922, en AAS., 14 (Ciudad del Vaticano, 1922), pp. 673-700. Utilizamos la numeración de la versión digital de la Librería Editrice Vaticana, 61.

${ }^{12}$ Pío XII, Discurso con motivo de la beatificación de Pío X, 3 de junio de 1951, en ÉL MISMO, Discorsi e radiomessaggi di sua Santità Pio XII, XIII Tredicesimo anno di Pontificato (2 marzo 1951-1 marzo 1952) (Città del Vaticano, Tipografía Poliglotta Vaticana, 1953), pp. 127-136; Pío XII, Discurso con motivo de la canonización de Pio X, 29 de mayo de 1954, en Él MisMo, Discorsi e radiomessaggi di sua Santità Pio XII, XVI, Sedicesimo anno di Pontificato (2 marzo 1954-1 marzo 1955), (Città del Vaticano, Tipografía Poliglotta Vaticana, 1956), pp. 32-37.

${ }^{13}$ Con distintos matices, estas tesis se encuentran en autores de gran valía y seriedad científica. Por todos, Vian, Giovanni, Il modernismo. La Chiesa cattolica in conflitto con la modernità (Roma, Carocci, 2012); y ARNOLD, Claus y VIAN, Giovanni (cur.), La condanna del modernismo. Documenti, interpretazioni, conseguenze (Roma, Viella, 2010). Más específicamente, VIAN, Giovanni, La riforma della Chiesa per la restaurazione cristiana della società. Le visite apostoliche delle diocesi e dei seminari d'Italia promosse durante il pontificato di Pio X (Roma, Herder, 1998), 2 vols.

${ }^{14}$ Valverde, Carlos, Génesis, estructura y crisis de la modernidad (Madrid, BAC, 1996), p. 234. Una problematización de esta postura en AlveAr TÉLLEZ, Julio, La libertad moderna de conciencia y de religión. El problema de su fundamento (Madrid-Barcelona, Marcial Pons, 2013), pp.48-182.

${ }^{15}$ Véase, por ejemplo, Robles Muñoz, Cristóbal, El modernismo religioso y su crisis, I: Preliminares (Madrid, ACCI, 2016); II: La condena 1906-1913 (Madrid, ACCI, 2017); III: Después de Pio X (Madrid, ACCI, 2017).

${ }^{16}$ Loisy confiesa abiertamente, después de la condena, que el objetivo es "cambiar la Iglesia, su constitución, su doctrina y sus ritos". LoIsY, Alfred, Simples réflexions sur le decret du Saint Office "Lamentabili Sane Exitu", et sur l'Encyclique "Pascendi Dominici Gregis" (Ceffond, près Montieren-Der, Haute-Marne, Chez l’Auteur, 1908), p.13. La misión de los modernistas, según Tyrell, 
ideológica hacia San Pio X en diversas investigaciones, que pesa como un "parti pris" que les condiciona. En ocasiones, la animadversión llega a extremos, como el caso de Henri Brémond s.j., quien, en su discurso de ingreso a la Academia Francesa, omite siquiera el nombre del pontífice cuando enumera los papas bajo cuyo pontificado ha vivido ${ }^{17}$.

En los últimos años ha surgido una línea más moderada, que sitúa a San Pío $\mathrm{X}$ en una postura intermedia, ambivalente. La lucha contra el modernismo no habría marcado a fuego su pontificado, como han pensado quienes le denigran y quienes le aplauden. Al lado de la actitud antimoderna habría operado una mímesis con algunas tendencias fundamentales de la modernidad. Una imitación por contraste u oposición por imitación ${ }^{18}$.

No podemos exponer en todos sus detalles y matices esta línea interpretativa. Se puede convenir, sin embargo, en que la obra de Romanato ejemplifica en lo grueso sus principales elementos. En el plano religioso, San Pío X pertenecería al "filón intransigente y antimoderno", pero en el ámbito de la organización eclesiástica y del derecho canónico, habría modernizado la iglesia, uniformándola según el modelo de estatalidad liberal posrevolucionaria ${ }^{19}$. Es más, la inmensa actividad reformadora en su conjunto muestra un pontificado que da primacía a lo espiritual-devocional por sobre las luchas por la sociedad terrena, lo que equivaldría a una "obra de modernización y no de restauración; de proyección a futuro y no de refugio en el pasado". San Pío X habría sido el "audaz reformador que cerró la etapa secular del temporalismo y proyectó el catolicismo hacia la modernidad" 20 .

La consecuencia es nítida: la centralidad del pontificado del papa Sarto no se encuentra en el modernismo, sino en la reforma moral, jurídica e institucional

es la de "golpear y golpear la vieja carcasa de la Iglesia Romana". Citado Por Sorel Climent, Jorge, El contexto histórico de la encíclica "Pascendi", en Verbo, 455-456 (Madrid, 2007), pp. 377.

${ }^{17}$ Citado por Madiran, Jean, Réflexions autour de La Cité Catholique, en Itinéraires, 62 (1962), p. 52.

${ }^{18}$ Fantappiè, Carlo, Chiesa romana e modernità giuridica. Il Codex iuris canonici (1917) (Milano, Giuffrè, 2008), p. 976, a propósito del Código de Derecho Canónico.

${ }^{19}$ Romanato, Gianpaolo, Pio X: studi e interpretazioni, en Anuario de Historia de la Iglesia, 23 (Pamplona, 2014), pp. 153-167. Sin embargo, respecto de la reforma jurídica, se ha destacado el sedimento no moderno de la codificación Pío-Bendecitina, con crítica al modelo de s o c i e d a d p e $\mathrm{r} f$ e c $\mathrm{t}$ a . Dalla Torre, Giuseppe, Il codice di diritto canonico, en La Bella, Gianni (cur.), Pio X e il suo tempo (Bologna, il Mulino, 2003), pp. 321-322. Una postura más equilibrada en De Ruschi, Luis María, Vigencia de la noción de Iglesia como sociedad jurídicamente perfecta y su anclaje en el derecho natural, en Verbo, 523-524 (Madrid, 2014), pp.239-261. Puede verse también, Cattaneo, Arturo (cur.), L'eredità giuridica di San Pio X(Venezia, Marcianum Press, 2006). Sobre la participación en la reforma jurídica, el notable trabajo de SALINAS ARANEDA, Carlos, La participación de los obispos del Perú en la codificación del derecho canónico de 1917 (Lima, PUCP- Instituto Riva-Agüero, 2012). Hay un aspecto cuya investigación queda abierta: hasta qué punto la codificación promulgada en época de Benedicto XV responde del todo a la línea de San Pío X, dada las diferencias que Gasparri manifestó respecto de este último.

${ }^{20}$ Romanato, Pio X: studi e interpretazioni, cit. (n. 19), p. 167. 
de la Iglesia ${ }^{21}$. Hay que sacar a San Pío X del eje del modernismo, para ubicarlo en un horizonte p a s o r a l y a p o lí t i c o, cuyo centro es la salusanimarun individual ${ }^{22}$.

Esta tesis se ha presentado como fruto de la apertura de los archivos vaticanos ${ }^{23}$. El problema es que no se deduce directamente de las fuentes; hay que emprender un enorme esfuerzo interpretativo para calzar sus conclusiones. Además, surge aquí la cuestión metodológica: la noción de modernidad y sus implicancias no se alcanza primariamente desde la interpretación histórico-biográfica, sino desde la valoración conceptual, doctrinal y filosófica. La modernidad no es un problema cronológico, sino axiológico y teorético ${ }^{24}$.

Mirada desde fuera de sus supuestos, se tiene la impresión de que esta línea interpretativa busca dividir el pontificado de San Pío X en dos ámbitos nítidamente diferenciados, cerrados y compactos. Todo con el fin de excusar (o eventualmente lamentar) la lucha contra el modernismo (primer ámbito) y aplaudir el impulso reformista (segundo ámbito), reinterpretado en clave "moderna”. Una modernidad, esta vez, en confuso, asumida como categoría genérica, sin límites conceptuales precisos, y que viene a significar dos cosas: en el presente, adaptación a los tiempos; en el futuro, carácter precursor de cara a las reformas posconciliares ${ }^{25}$.

El modernismo, sin embargo, es un fenómeno que va más allá de las manifestaciones concretas a la época de San Pío X. El papa Sarto se opuso a esas manifesta-

\footnotetext{
${ }^{21}$ Ibíd. La tesis más ampliamente desarrollada en Romanato, Gianpaolo, Pio X. Alle origini del cattolicesimo contemporáneo (Torino, Lindau, 2014).

${ }^{22}$ Tramontin, Silvio (cur.), Le radici venete di San Pio X (Morcelliana, Brescia, 1987), p. 217.

${ }^{23}$ Dieguez da una pista de esta línea interpretativa al sostener que los nuevos elementos de investigación permiten liberar la imagen del pontífice tanto "de aquellos que lo habían elevado al baluarte del tradicionalismo más obtuso" como "de aquellos que lo había convertido en el blanco de todas las acusaciones de anti-modernismo intemperante”. Dieguez, Alejandro, La nuova documentazione dell'Archivio Vaticano per una migliore comprensione della figura e opera di Giuseppe Sarto-Pio X, en Anuario de Historia de la Iglesia, 23 (Pamplona, 2014), p. 185. La documentación corresponde a los fondos de la Secretaria de Estado, de la Congregación Consistorial, del Archivo particular de Pío X y de sus cartas. La conclusión de Dieguez es válida si con ello se quiere indicar la temperancia y prudencia del Pontífice en el gobierno de la Iglesia. Dada la energía utilizada en la lucha contra el modernismo, desde temprano los adversarios del papa objetaron intolerancia y desmesura. Incluso personeros eclesiásticos de alta importancia, como el cardenal Pietro Gasparri, depusieron en el proceso de beatificación alegando imprudencia gubernativa. Fruto de ello es el informe del P. Antonelli titulado Disquisitio circa quasdam objectiones modum agendi servi Dei respicientes in modernismo debellatione, que concluye en favor del papa Sarto. En este punto, Pío XII resaltó su "firmeza contra el error", encomiando en el lenguaje clásico de las virtudes su "celo apostólico", su "prudencia" sobrenatural, su "fortaleza", su "solicitud pastoral por la libertad de la Iglesia, por la pureza de la doctrina, por la defensa del rebaño de Cristo". Pío XII, Discurso con motivo de la beatificación de Pio X, cit. (n. 12), p. 131.

${ }^{24} \mathrm{La}$ distinción entre modernidad cronológica y modernidad axiológica o teorética, en Castellano, Danilo, L'ordine della politica. Saggi sul fondamento e sulle forme del politico (Napoli-Roma, Edizioni Scientifiche Italiane, 1997), p. 56.

${ }^{25}$ Sobre la unidad fundamental del cuerpo doctrinario de San Pío X desde el ángulo de la piedad, CABello, Emmanuel, La renovación de la vida cristiana, en Anuario de Historia de la Iglesia, 6 (Pamplona, 1997), pp. 45-60.
} 
ciones con mirada clarividente, pero no las derrotó. Sobrevivieron y han vuelto a resurgir, particularmente en el terreno religioso (con una espectacular expansión a partir de la década de los sesenta) y en el plano político-social (sea en su vertiente totalitaria, sea en su vertiente democrático-liberal) ${ }^{26}$.

Es por ello que la lectura antimoderna de San Pío X es, a nuestro juicio, la única que comprende a cabalidad y en todas sus implicancias la línea de pensamiento del pontífice. En continuidad con sus predecesores, el papa Sarto quiso destacar el núcleo teológico y filosófico de la modernidad axiológica (no cronológica), con sus aplicaciones en el ámbito dogmático y científico, pero también en el orden político-temporal.

En el pensamiento católico se han ofrecido diversas categorías para caracterizar la esencia de la modernidad axiológica ${ }^{27}$. Todos estos elementos se encuentran implicados en el modernismo rechazado por San Pío X. Y es que el modernismo representa la aceptación del pensamiento moderno al interior del catolicismo. De ahí su pretensión de permanecer dentro de la iglesia para modificarla ad intra desde los horizontes de la modernidad axiológica, conjugando para ese fin las distintas disciplinas (la exégesis, la dogmática, las ciencias históricas, la antropología, la moral y la retórica política) ${ }^{28}$.

El modernismo designa primariamente una actitud intelectual, un espíritu o tendencia en la que subyace una cosmovisión filosófica del mundo y de la re-

${ }^{26}$ Castellano, Danilo, El modernismo político y social, cit. (n. 8), p. 425

${ }^{27}$ Gambra sostiene que el racionalismo es la esencia de la modernidad, lo que paradójicamente supone un acto de fe en la capacidad de la $\mathrm{r}$ a z ó n p u r a para rehacer el mundo, con la revolución como vía privilegiada para lograrlo. GAMBRA, Rafael, Eso que llaman Estado (Madrid, Montejurra, 1958), pp. 53, 198; y GamBra, Rafael, Historia sencilla de la filosofía (24a ed., Madrid, Rialp, 1999), pp.152-153. Corrêa de Oliveira afirma que la esencia de la modernidad es la R e v o 1 u c i ó n (con "R" mayúscula), un intento fáustico para destruir la civilización cristiana y el orden de la creación, erradicando -si posible fuese- los frutos de la Redención y los vestigios de la Creación. CORRÊA DE OLIVEIRA, Plinio, Revolución y contra-revolución (2a ed., Santiago de Chile, Editorial Apóstol Santiago, 1992), pp. 66-67. Fabro observa que el pensamiento moderno en sus múltiples variantes depende siempre del principio de inmanencia. FABRO, Cornelio, Introduzione all'ateismo moderno (Roma, Studium, 1969), p. 1003. De ahí derivan, según Del Noce, el ateísmo postulatorio como actitud radical y la interpretación de la historia como secularización y desmitificación, amparada por el mito del progreso. DeL NocE, Augusto, Tramonto o eclissi dei valori tradizionali?, en SPIRITo, U.; Del Noce, A, Tramonto o eclissi dei valori tradizionali? (Milano, Rusconi, 1971), pp. 147-148, 182. Desde el ángulo de sus principios filosóficos basales, la modernidad no es divisible. Castellano, Danilo, La politica tra Scilla e Cariddi (Napoli-Roma, Edizioni Scientifiche Italiane, 2010), pp. 87-96.

${ }^{28}$ En sus orígenes histórico-doctrinales, el modernismo fue influido hondamente por el protestantismo liberal, el triunfo de la estructura política de la Revolución Francesa, el ideal mítico del progreso científico y la filosofía de la historia ilustrada, por donde se creen conocer las leyes evolutivas de la humanidad. Dumont, Bernard, El modernismo después de la encíclica "Pascendi", en Verbo, 455-456 (Madrid, 2007), pp. 433-434. En este contexto, el verdadero pecado para el cristianismo pasa a ser el "no cooperar al proceso evolutivo del mundo". FABRO, Cornelio, L'avventura della teologia progresista (Milano, Ruscone, 1974), p. 221. 
ligión. Su núcleo doctrinario puede formularse de diversas maneras. Pascendi le caracteriza con las notas del agnosticismo, la inmanencia vital y el subjetivismo ${ }^{29}$.

Hay que notar que esta descripción fue reconocida como sustancialmente correcta por los modernistas de la época, sin perjuicio de sus consabidos reclamos estratégicos $^{30}$.

Sin perjuicio de ello, hay diversas maneras de formular los principios basales del modernismo. José Miguel Gambra los recoge en tres doctrinas procedentes del pensamiento moderno: idealismo, agnosticismo e inmanentismo religioso ${ }^{31}$. Danilo Castellano nota que hay un presupuesto común, más radical, que es la "inmanencia como filosofía" 32 .

El modernismo tiene una peculiaridad: dada su naturaleza esencialmente evolutiva, es dúctil y presenta una gran heterogeneidad en sus diversas manifestaciones teóricas, con una "extraordinaria capacidad de adaptación". De ahí la dificultad para sistematizarlo. En este sentido, Lamentabili y Pascendi constituyen un extraordinario esfuerzo por fijar en unos cuantos puntos centrales el eje del modernismo religioso y filosófico, como Note Charge Apostolique y Vehementer nos lo son respecto del modernismo propiamente político ${ }^{33}$.

$\mathrm{Y}$ es que modernismo religioso y político son correlativos a diversos títulos.

${ }^{29}$ Pío X, San, Encíclica "Pascendi Dominici gregis", 8 de septiembre de 1907 sobre el modernismo; original latino en ASS., 40 (Roma, 1907), pp. 593-650. Utilizamos la numeración de la versión digital de la Librería Editrice Vaticana, 4 a 16. Sobre el desarrollo doctrinario del modernismo, la bibliografía es inmensa y conocida en lo sustancial. Entre otros, los trabajos de Rivière, Marle, Poulat, García de Haro, Lome y Bolnad.

${ }^{30}$ En respuesta a la encíclica, se difundió, sin firma, el famoso "programa de los modernistas", donde se reconoce el acierto doctrinario del documento pontificio. ll programma dei modernisti (Turin, Bocca, 1911), pp. 99 y 112. Giovanni Gentile escribe en 1908 que Pascendi es "una magistral exposición y una magnifica critica de los principios filosóficos de todo el modernismo [...]. El autor de la encíclica ha comprendido perfectamente y ha interpretado con exactitud la doctrina subyacente en las exigencias filosóficas, teológicas, apologéticas, históricas, críticas y sociales del enfoque modernista". Gentile, Giovanni, Il modernismo e l'enciclica "Pascendi", en Él Mismo, Il modernismo e i suoi rapporti fra religione e filosofía, Opere (Florencia, Sansoni, 1962), XXXV, pp. 49-50.

${ }^{31}$ Gambra, José Miguel, El modernismo filosófico, en Verbo, 455-456 (Madrid, 2007), pp. 398-408.

${ }^{32}$ En el caso del modernismo religioso se concreta en "la absoluta inmanencia de lo divino en la historia”. Castellano, Danilo, De Christiana Republica (Napoli-Roma, Edizioni Scientifiche Italiane, 2004), p. 67. Desde el campo no católico, también se han caracterizado los principios del modernismo desde la inmanencia. Gentile destaca que su eje es la inmanentización de lo divino. Croce apunta a una religión de la inmanencia, sucesora del cristianismo. Respectivamente, Gentile, cit. (n. 30), p. 46; y Croce, Benedetto, Storia d'Europa nel secolo decimonono (Bari, Laterza, 1938), p. 26. La inmanencia como filosofía puede ser traducida en cinco principios. Son las bases a partir de las cuales razona la corriente modernista: el principio del subjetivismo; el principio de la razón inmanente, y, por tanto, 1 i b r e ; el principio de la verdad como identidad del espíritu; el principio de la religión como necesidad inmanente satisfecha por la elaboración racional; y el principio de la democracia. Castellano, cit. (n. 30), p. 67.

${ }^{33}$ Gambra, José Miguel, cit. (n. 31), pp. 409 y 414; Vegas Latapie, Eugenio, El modernismo después de la "Pascendi", en Verbo, 65-66 (Madrid, 1968), pp. 383-384. 
Hay, en primer lugar, una motivación de índole política ${ }^{34}$. En segundo lugar, presupuestos conceptuales comunes ${ }^{35}$. Y, asimismo, vínculos históricos claros ${ }^{36}$.

En este punto, se ha dicho que la lucha antimodernista de San Pío X fue profética $^{37}$. En la medida en que explicita aspectos nucleares de la modernidad axiológica, conserva una vigencia abarcadora, sobre todo en los días que corren.

Esto es especialmente notorio tratándose del modernismo político y social, que ha resurgido con gran fuerza a partir de la II Guerra Mundial, debilitando el derecho público cristiano, hasta convertirlo en un gran desconocido. Sin embargo, los principios de este último son perennes y tienen mucho que decir ante las alternativas del socialismo, el liberalismo y las ideologías débiles de la posmodernidad, sometidas todas a un creciente proceso de sospecha y de contestación.

De ahí la importancia de volver a sistematizar el corpus político de San Pío $\mathrm{X}$ desde el horizonte antimoderno.

\section{El Corpus politicum de San Pío X: las claves correctas de INTERPRETACIÓN}

El Corpus politicum de San Pío X se inserta en el vasto horizonte de rechazo del magisterio pontificio decimonónico a la modernidad axiológica, ámbito en donde explicita aspectos de relevancia. Lo estudiaremos directamente desde

${ }^{34}$ La motivación de índole política (en el sentido de interés por la ciudad) existe en el movimiento modernista como un proyecto de conformar una nueva sociedad, tanto civil como religiosa, de acuerdo a los ideales e $\mathrm{m}$ a n c i p a d o r e s de la modernidad, en mayor o menor grado. Gambra, cit. (n. 31), pp. 416-418. También Dumont, cit. (n. 28), pp. 440-444. Sobre los ideales e $\mathrm{m}$ a n c i p a d o r e s de la modernidad, AlveAr Téllez, Julio, La crítica aldiscurso de los derechos humanos. El origen (Valencia, Tirant lo Blanch, 2018), pp. 167-258, 337-380.

${ }^{35}$ Una vez comprendido los principios filosóficos del modernismo religioso, no es difícil medir sus proyecciones políticas y sociales. A este propósito, Danilo Castellano subraya un sintomático texto de la Pascendi: "cuando tratamos del modernismo, no hablamos de doctrinas [...] sin ningún vínculo de unión entre sí, sino de un cuerpo definido y compacto, en el cual si se admite una cosa de él, se siguen las demás por necesaria consecuencia”. Pío X, San, cit. (n. 29), p. 38. A partir de ahí, el filósofo italiano identifica las bases esenciales del modernismo político-social: origen inmanente de la potestad política; desconocimiento de la legitimidad de ejercicio; democracia como fundamento del gobierno; separación de la Iglesia y el Estado como principio; consecuente sujeción de la Iglesia al Estado; inestabilidad institucional y ordinamental. Castellano, cit. (n. 32), pp. 67-71.

${ }^{36}$ Desde el punto de vista histórico, las distintas manifestaciones del modernismo al interior de la Iglesia se unen como eslabones de una misma cadena. Modernismo religioso, liberalismo católico, americanismo, sillonismo democratista, etc., son facetas de la penetración de la modernidad en el pensamiento eclesiástico. Un análisis de los vínculos, desde distintos ángulos, Canals Vidal, Francisco, Cristianismo y revolución (2a ed., Madrid, Speiro, 1986); Meinvielle, Julio, De Lamennais à Maritain (Poitiers, Dominique Martin Morin, 2001); Havard DE LA Montagne, Robert, Histoire de la démocratie chrétienne de Lamennais à Georges Bidault (París, Amiot et Dumont, 1948); Gambra, Andrés, Los católicos y la democracia. Génesis histórica de la democracia cristiana, en Los católicos y la acción política, (Madrid, Speiro, 1982), pp. 11-284; Castellano, cit. (n. 32), pp. 65-86.

${ }^{37}$ Ayuso, Miguel, cit. (n. 8), pp. 457-466. 
las fuentes. Es imperativo volver a ellas para aquilatar la amplitud de la mirada antimoderna y comprender sus razones.

Para tales efectos, identificamos, en primer lugar, el enfoque desde el que papa se aproxima y juzga al mundo moderno. Este es susceptible de rechazo en la medida en que constituye una filosofía, una cosmovisión y un proyecto que se opone al Instaurare omnia in Christo ${ }^{38}$. En segundo lugar, se analiza el modernismo histórico, el que le tocó enfrentar el pontífice con sus proyecciones temporales, y que, desde este cuadro, no es otra cosa que la penetración del pensamiento moderno en el seno del catolicismo. Finalmente, nos detenemos en los elementos esenciales de la modernidad política, que con sus sistemas va aniquilando paulatinamente el derecho público cristiano, dimensión político-jurídica de la civilización fundada en el cruz. En este sentido, la actitud antimoderna no es pura negatividad, sino que responde a un designio sumamente positivo: la restauración de la civilización cristiana, como modelo político-temporal.

Una prevención importante. En San Pío X, como en León XIII, es oportuno distinguir entre magisterio -el corpus politicum propiamente tal- y gobierno pontificio; entre la afirmación doctrinal y la política eclesial que la mediatiza. Si bien, como indicamos al inicio, este trabajo se centra en el estudio de la doctrina en sí misma considerada, hay que connotar que a ella le acompaña una pastoral que puede o no ser diferenciable. Y cuando lo es, se hace oportuno destacarlo por su interés histórico. En el caso del papa Sarto -o de su Secretaría de Estado- hay una línea política en Italia y España que parece matizar en mayor o menor grado la aplicación de los principios doctrinales, sea por motivos prudenciales, sea por razones diplomáticas ${ }^{39}$.

${ }^{38}$ Pío X, San, Encíclica "Supremi apostolatus", 4 de octubre de 1903. Acta Sanctae Sedis, 36 (Roma, 1903-1904), pp. 129-139 (en adelante ASS.). Utilizamos la numeración de la versión digital de la Librería Editrice Vaticana, 4.

${ }^{39}$ No obstante la condena tajante de la democracia moderna, la Secretaría de Estado de San Pío X promovió la participación de los católicos en las elecciones administrativas italianas para enfrentar al liberalismo. Utilizó la democracia contra este último. Una evaluación en CASTELLANO, Danilo, La tradición politica católica frente a las ideologias revolucionarias (Madrid, Consejo de Estudios Hispánicos, 2019), pp. 113-122, 136. En España, ante la polémica que dividía a los partidos católicos (tradicionalistas contra pidalistas, transaccionales, etc.), el papa Sarto publica la Inter catholicos Hispaniae (20 de febrero de 1906), admitiendo que no es deplorable la doctrina del mal menor defendida por la revista jesuita Razón y Fe (ante el peligro del radicalismo socialista o anarquista, es lícito votar a un candidato que no defienda la tesis de la unidad católica en su integridad, si da garantías de respetar la religión y la patria). A esta siguen las Autorizadas instrucciones a los católicos (30 de enero de 1909) y las Normas sobre conducta política (20 de abril de 1911). Los documentos los expone García Ortí, Vicente, San Pio X, los jesuitas y los integristas españoles, en Archivum Historiae Pontificiae, 27 (Roma, 1989), pp. 279-280, 302-304, 322-325, respectivamente. El papa Sarto y el cardenal Merry del Val optaron por sumar fuerzas contra los adversarios más incisivos de la Iglesia en vez de dar un espaldarazo exclusivo al sector tradicionalista. Sin dejar de privilegiar la tesis de la unidad católica que estos sostenían, les urge a la unión, aunque sin aconsejar la aceptación del régimen (como lo había hecho León XIII), por lo que el carlismo podía seguir defendiendo sus "legítimas opciones políticas". Para una 


\section{Diagnóstico y pronóstico de la modernidad axiológica}

En E Supremi apostolatus, San Pío X examina la situación en que se encuentra la humanidad, especialmente las naciones cristianas, caracterizadas por la apostasía social y el rechazo a la ley divino-natural en el ámbito público.

\section{a) La apostasía de las naciones}

E Supremi apostolatus ratifica los juicios de León XIII sobre la apostasía de la sociedad occidental, esto es, la defección y separación de Dios de los pueblos cristianos $^{40}$. Tal apostasía se formaliza en la aceptación política y social de los proyectos laicos. Dichos proyectos son sintomáticos, pues indican la existencia de una lucha contra Dios, de tal ímpetu y profundidad en lo colectivo, que sólo pueden ser considerados como un preanuncio de los tiempos del Anticristo ${ }^{41}$.

San Pío X previene que la civilización cristiana será restaurada, y, por ende, resurgirá la sociedad política católica en sus principios permanentes. Mientras tanto, el remedio no está la solución de compromiso, sino en la respuesta cristiana al proyecto moderno ${ }^{42}$.

\section{b) las huestes modernas contra el Crucificado}

Communium rerum ${ }^{43}$ enfoca el proceso de la modernidad como una guerra contra Dios y la Iglesia, en lo que parece seguir la interpretación de Annum ingressi de León XIII. El documento preanuncia el “triunfo de Dios sobre la tierra” y la vuelta de las naciones a la fe. Pero lamenta que en el interregno quienes dirigen las sociedades cristianas prefieran las libertades modernas -ya definidas como licencia para el mal-al reinado social de Cristo $^{44}$.

Como nunca antes en la historia, la obra de la redención, que se expresa temporal y socialmente en la civilización cristiana, está siendo objeto del ataque

distinción adecuada entre carlismo e integrismo en este problema, FERRER, Melchor, Historia del tradicionalismo español (Sevilla, Editorial Católica Española, 1959), XVIII/1, pp. 283-285. Sobre el mal menor, la lógica de la argumentación de Nocedal y su influencia en el catolicismo no tradicional, Alférez, Gabriel, El mal menor en política. Historia y aplicaciones actuales, en Verbo, 269-270 (Madrid, 1988), pp. 1237-1258.

${ }^{40}$ Pío X, San, Supremi apostolatus, cit. (n. 38), 3.

${ }^{41}$ Ibíd., 4 y 5, con cita a pasajes apocalípticos de San Pablo. La sociedad moderna será golpeada por dos vías subsecuentes: la ceguera respecto de lo divino (ya indicada por León XIII) y la aniquilación de sus estructuras. No detalla el papa de qué manera esto se realizará; sólo advierte que el ímpetu de autonomía antiteísta será humillado. A una década de la Primera Guerra Mundial, el documento anuncia que los anhelos de paz sin el Dios cristiano son vanos para Europa. Pío X, San, Supremi apostolatus, cit. (n. 38), 6 y 7.

${ }^{42}$ Pío X, San, Supremi apostolatus, cit. (n. 38), 8 y 9.

${ }^{43}$ Pío X, San, Encíclica "Communium rerum”, 21 de abril de 1909. Acta Apostolicae Sedis, 1 (Ciudad del Vaticano, 1909), pp. 333-388 (en adelante $A A S$.). Utilizamos la numeración de la versión digital de la Librería Editrice Vaticana.

${ }^{44}$ Ibíd., 4 y 13. 
astuto de parte de enemigos externos conjurados para su demolición bajo la bandera de la libertad ${ }^{45}$.

Pero los más peligrosos son los enemigos internos que pretenden alterar la doctrina de la iglesia para establecer alianzas con la revolución, no sólo en el campo de la teología y la filosofía, sino también en la doctrina política y su realización histórica ${ }^{46}$.

La exclusión de Dios de la sociedad temporal es inadmisible ${ }^{47}$. De donde el laicismo de Estado no se puede admitir bajo ningún respecto como un bien.

\section{Infiltración de la modernidad axiológica en el catolicismo y sus proyecciones temporales}

Hemos estudiado Pascendi en la primera parte de este trabajo. Aquí debemos destacar dos cosas. Primero, que su objetivo es develar la infiltración del espíritu moderno dentro del catolicismo, así como su génesis doctrinal y sus postulados teóricos y teórico-prácticos esenciales. Segundo, que se hace una aplicación de las condenas del Syllabus y del Concilio Vaticano I a los e r r o r e s m o d e r n o s. Una de las manifestaciones más relevantes de esos errores es el racionalismo.

Lamentabili formula con precisión los errores del racionalismo acerca de la posibilidad y naturaleza de la verdad revelada ${ }^{48}$. Sacrorum antistitum previene que tales errores no son sólo un equívoco del entendimiento humano, pues tienen un origen moral y se proyecta a todos los campos ${ }^{49}$. Doctoris angelici expresa que en la filosofía de Santo Tomás de Aquino, especialmente en su metafísica, se encuentra el eficaz antídoto contra el racionalismo, sus manifestaciones y sus consecuencias políticas como el liberalismo y el socialismo ${ }^{50}$.

\footnotetext{
${ }^{45}$ Ibíd., 13.

${ }^{46}$ Ibíd., 15 y 16, con alusión expresa al m o d e $\mathrm{r} \mathrm{n}$ i s $\mathrm{m}$ o y sus proyecciones en el campo político.

${ }^{47}$ Ibíd., 24. El agnosticismo contemporáneo utiliza incluso el progreso de la ciencia, que en sí es algo bueno, para alejar de Dios. Pío X, San, Encíclica "Iucunda sane", 12 de marzo de 1904, en ASS., 36 (Roma, 1903-1904), pp. 515-529. Utilizamos la numeración de la versión digital de la Librería Editrice Vaticana, 5, 16 y 17.

${ }^{48}$ Véase las proposiciones 1, 9, 11-18, 20, 22, 25-27, 29, 36, 53, 54, 57-60, 6365. Expresiva es la proposición 20 que connota el subjetivismo; la prop. 22 que niega la objetividad sobrenatural del contenido de fe; las props. 54, 58 y 64 que connotan el evolucionismo y el relativismo. Finalmente, destacamos la prop. 65 que parece una aplicación de la proposición 80 del Syllabus en el ámbito de la doctrina cristiana: "El progreso de las ciencias demanda que se reformen los conceptos de la doctrina cristiana sobre Dios, la creación, la revelación, la persona del Verbo Encarnado y la redención”. Pío X, San, Decreto del Santo Oficio "Lamentabili sine exitu", 3 de julio de 1907. ASS., 40 (Roma, 1907), pp. 470-478. Se rechazan 65 proposiciones tomadas de las obras de Loisy, Tyrrel, Le Roy y Blondel.

${ }^{49}$ Pío X, San, Motu proprio "Sacrorum antistitum", 1 de diciembre de 1910, establece el juramento anti-modernista, en $A A S$., 2 (Ciudad del Vaticano, 1910), pp. 655-680.

${ }^{50}$ Pío X, San, Motu proprio "Doctoris angelici", 29 de junio de 1914 sobre el estudio de la doctrina de Santo Tomás de Aquino. AAS., 6 (Ciudad del Vaticano, 1914), pp. 336-341. En otro lugar hace un interesante análisis acerca de la virtualidad del dogma de la
} 
El racionalismo se mueve en varias direcciones: i) en el a g n o s t i c is m o, que rechaza la metafísica implicada en la teología natural así como los motivos de credibilidad respecto de la revelación cristiana ${ }^{51}$; ii) en el n a t u r a 1 i s m o, que niega, de plano, la posibilidad y la existencia de un orden sobrenatural ${ }^{52}$; iii) en el progresis mo, que deserta de la autoridad magisterial de la iglesia, al someter el contenido de la fe a los criterios cambiantes de una razón humana autónoma, embridada por el mito del progreso evolutivo ${ }^{53}$; iv) en ell a i c i s m o, y la tesis de la separación de la Iglesia y el Estado, y el subsiguiente sometimiento de la primera al segundo. Si la fe y la ciencia son extrañas entre sí en virtud de su objeto, el Estado y la Iglesia también son extraños en razón de sus fines temporal y espiritual. El Estado debe separarse de la Iglesia como el católico del ciudadano $^{54}$. El nervio de la argumentación modernista es el supuesto progreso moral que ha traído la revolución con su conciencia de libertad, autonomía y emancipación.

Consecuencia de la tesis precedente es que el Estado reivindica soberanía sobre toda la esfera de la vida pública, por lo que la Iglesia debe quedar sometida en sus actos exteriores al orden público definido por la legalidad laica ${ }^{55}$. Esto conlleva un resultado colateral de enorme importancia: la concentración en manos del Estado de la potestad para delimitar lo bueno y lo malo en la vida pública, que antes pertenecía como última ratio a la autoridad de la Iglesia.

El laicismo, en su filiación racionalista, considera incognoscible la fe y la moral cristiana. Es lógico, por tanto, que los excluya como principios de la sociedad política.

\section{La civilización cristiana como respuesta al proyecto moderno fáustico}

a) la definición esencial

Il fermo proposito ${ }^{56}$ define los elementos esenciales de la civilización cristiana, considerada como modelo de toda civilización. La definición se realiza sobre la base de las relaciones entre la Iglesia y la sociedad política. Se puede sistematizar en los siguientes elementos: i) la misión de la Iglesia es primordialmente de naturaleza espiritual: santificación de las almas y difusión del Reino de Dios

Inmaculada Concepción para deshacer el racionalismo. Pío X, San, Encíclica "Ad diem illud laetissimum”, 2 de febrero de 1904. ASS., 36 (Roma, 1903-1904), pp. 449-462.

${ }^{51}$ Pío X, San, Pascendi, cit. (n. 29), 4 y 39.

${ }^{52}$ Ibíd., 4 y 8.

${ }^{53}$ Ibíd., 25-27.

${ }^{54}$ Ibíd., 23.

${ }^{55}$ Ibíd., 24. El modernismo, sostiene el pontífice, pretende reducir la potestad de jurisdicción de la Iglesia a una función de consejo, que, en todo caso, represente en el ámbito colectivo eclesial la conciencia de sus seguidores.

${ }^{56}$ Pío X, San, Encíclica "Il fermo propósito", 11 de junio de 1905. ASS., 37 (Roma, 19041905), pp. 741-767. Utilizamos la numeración de la versión digital de la Librería Editrice Vaticana. 
en los individuos, en las familias y en la sociedad, mediante la extensión de la fe y la moral, el ejercicio de las virtudes cristianas y las obras de caridad espiritual y corporal ${ }^{57}$; ii) al cumplir con su misión, la Iglesia necesariamente inspira y da forma a una civilización, orientando todo el orden temporal hacia Cristo; iii) la fe y la ley cristiano-natural al elevar hacia sí todas las facultades humanas, atraen todo el ámbito secular de la cultura, de las ciencias, de las artes, de las instituciones políticas, de las leyes, de las costumbres sociales e incluso del bienestar material ${ }^{58}$; iv) la Iglesia al evangelizar civiliza, pues los bienes cristianos perfeccionan la naturaleza humana. Y, salvo que la Iglesia renuncie a ejercer su misión, la evangelización produce n e c e s a r i a m e n t e una civilización cristiana, como puede probarse históricamente ${ }^{59}$; v) la civilización cristiana es el padrón de toda civilización humana ${ }^{60}$; vi) la comunidad política católica es un aspecto esencial de la civilización cristiana. Implica la orientación del poder y la dirección eficaz del bien común hacia el fin último del hombre, que trasciende esta tierra. De ahí los deberes de profesión de la fe en la vida pública, el imperio de la ley divino-natural en las leyes positivas, y la concordia entre la Iglesia y el Estado. Con ello se conforma un derecho público cristiano ${ }^{61}$; vii) el pontífice habla de Estado (Stati) y no de sociedad política, aunque conceptualmente parece tener en mente la segunda, atendida su concepción asociativa del orden socio-político, en el que la familia y los cuerpos intermedios tienen un papel fundamental. De todas formas, sea una sociedad política católica o en un Estado confesional, se excluye necesariamente el laicismo y las libertades modernas, tanto desde el punto de vista de la sociedad, que reconoce la autoridad magisterial de la Iglesia (no sus abusos), como del poder político que se somete a la ley y cristiana coopera con aquella, removiendo, en lo que le cabe, los obstáculos temporales que impiden la obtención del fin último del hombre; viii) siguiendo a sus predecesores, San Pío X constata que la revolución moderna ha emprendido una $\mathrm{g} u$ e $\mathrm{r} r$ a para que la sociedad se rija por principios

\footnotetext{
${ }^{57}$ Ibíd., 3.

${ }^{58}$ Ibíd., 4.

${ }^{59}$ Ibíd.

${ }^{60}$ Ibíd. "La civiltà del mondo è civiltà cristiana; tanto è più vera, più durevole, più feconda di frutti preziosi, quanto è più nettamente cristiana; tanto declina, con immenso danno del bene sociale, quanto allidea cristiana si sottrae. Onde, per la forza intrinseca delle cose, la Chiesa divenne anche di fatto custode e vindice della civiltà cristiana. E tale fatto in altri secoli della storia fu riconosciuto e ammesso; formò anzi il fondamento inconcusso delle legislazioni civili".

${ }^{61}$ Ibíd. "E tale fatto in altri secoli della storia fu riconosciuto e ammesso; formò anzi il fondamento inconcusso delle legislazioni civili. Su quel fatto poggiarono le relazioni tra la Chiesa e gli Stati, il pubblico riconoscimento dell'autorità della Chiesa nelle materie tutte che toccano in qualsivoglia modo la coscienza, la subordinazione di tutte le leggi dello Stato alle divine leggi del Vangelo, la concordia dei due poteri dello Stato e della Chiesa, nel procurare in tal modo il bene temporale dei popoli, che non ne abbia a soffrire l'eterno".
} 
adversos a los que inspiran la civilización cristiana. Desde el punto de vista de las causas teológicas, este proceso es conducido por los enemigos de Dios. El laicismo de los estados modernos hace parte de ese plan ${ }^{62}$; ix) la restauración de todas las cosas en Cristo, implica no sólo la restauración de las cosas divinas en el orden eclesial, sino también la restauración de la civilización cristiana ${ }^{63} ; \mathrm{x}$ ) en Notre charge apostolique $e^{64}$ se hace una descripción de lo que debe entenderse por civilización cristiana connotando sus tres componentes fundamentales: el orden social-natural, la tradición histórica cristiana y el orden sobrenatural ${ }^{65}$. San Pío X habla de "principios", de "fundamentos naturales y divinos sobre los que se asienta la civilización cristiana” (civilisation chrétienne), la ciudad católica (cité catholique), lo que revela que tales principios y fundamentos son indelebles, perennes, y no está en manos del hombre -tampoco de los hombres de Iglesiaobviarlos con cómodos compromisos con el laicismo.

\section{b) el espiritu moderno y el despliegue de la autonomía inmanentista}

Il grave dolore ${ }^{66}$ actualiza la proposición ochenta del Syllabus, al reiterar la

${ }^{62}$ Ibíd., 5.

${ }^{63}$ Ibíd., 6. "La Chiesa va quindi innanzi imperterrita, e mentre diffonde il Regno di Dio là dove non fu peranco pregiudicato, si studia per ogni maniera di riparare alle perdite nel Regno già conquistato. 'Restaurare tutto in Cristo'è stata sempre la divisa della Chiesa, ed è particolarmente la Nostra nei trepidi momenti che traversiamo. Ristorare ogni cosa, non in qualsivoglia modo, ma in Cristo: 'in Lui, tutte le cose che sono in Cielo ed in terra', soggiunse l'Apostolo (Eph. I, 10): ristorare in Cristo non solo ciò che appartiene propriamente alla divina missione della Chiesa di condurre le anime a Dio, ma anche ciò che, come abbiamo spiegato, da quella divina missione spontaneamente deriva, la civiltà cristiana nel complesso di tutti e singoli gli elementi che la costituiscono". Ibíd. 8, se indican esos elementos: la familia, la escuela, la autoridad política, la sociedad temporal, etc. Ibíd., 9, se advierte que la restauración debe ser preparada al amparo de nuevas circunstancias, pues no todo lo útil en el pasado puede serlo hoy. Sobre la restauración de la civilización cristiana es conocido el pasaje de Notre charge apostolique, 11.

${ }^{64}$ Pío X, San, Encíclica "Notre charge apostolique", 25 agosto de 1910. AAS., 2 (Ciudad del Vaticano, 1910), pp. 607-633. A pesar de su importancia, no se encuentra en el sitio digital de la Librería Editrice Vaticana. Utilizamos la numeración de GuTiÉrREz García, José Luis, Doctrina pontificia, II: Documentos politicos (Madrid, BAC, 1958), pp. 404-423.

${ }^{65}$ Se trata de una civilización que se edifica teniendo como base el orden n a t u r a 1 . Lo que supone la sumisión constitutiva de la sociedad a la ley natural y al orden del desenvolvimiento de las distintas facultades humanas, espirituales, emocionales y físicas en el ámbito individual y social. El segundo elemento es la t r a d i c i ó n. Esto es, el aprecio activo del legado de bienes de diversa índole -culturales, educativos, políticos, jurídicos, artísticos, de identidad simbólica, etc.- que son frutos de la actualización histórica de las facultades y virtudes que el hombre desarrolla en el conjunto de cuerpos asociativos que vitalmente se componen a partir de la familia -en todo su vigor- en un tiempo determinado. El tercer elemento es, por así decirlo, el constitutivo formal de la civilización cristiana: $l a f e$, que implica el reconocimiento por parte de la sociedad y sus estructuras políticas de la verdad divina que guarda la Iglesia y del imperio de la ley divino-natural.

${ }^{66}$ Pío X, San, Il grave dolore, cit. (n. 10), p. 260. 
incompatibilidad entre la fe cristiana y el espíritu moderno. Lo notable es que caracteriza a este último como la conciencia política y laica opuesta al cristianismo ${ }^{67}$.

Primum vos $^{68}$ recuerda que la Iglesia tiene autoridad sobre los gobernantes en materia social y política en lo que respecta al orden natural y revelado ${ }^{69}$. En este sentido, las libertades modernas son ilegítimas en la medida en que suponen la facultad ilimitada de obrar sin atención a la autoridad divina y humana y a las bases naturales y cristianas de la sociedad política ${ }^{70}$.

La modernidad no es rechazable por el progreso de las ciencias en sí mismas consideradas, sino por sus principios filosóficos y sus consecuencias políticas que llevan al hombre a querer liberarse de la ley ${ }^{71}$. En este plano, existe una retroalimentación entre el laicismo y la decadencia de las costumbres. No puede pensarse en una restauración si el poder político no reconoce formalmente al Dios cristiano y su imperio, y los hombres no se regeneran en su interior con la práctica de las virtudes ${ }^{72}$.

San Pío X vislumbra enormes trastornos en el orden social y político. Las guerras mundiales y la emergencia del totalitarismo están a un paso. Es el emerger de la dimensión disgregadora -no prevista por los modernos pero anunciada ya por León XIII- de los Estados laicos que han rechazado asentarse sobre "la piedra angular de la sociedad humana"73. El gran error en este punto ha sido la negación del orden trascendente ${ }^{74}$.

\section{El Corpus politicum de SAn Pío X: los PRincipios antimodernos}

San Pío X recoge el corpus politicum leonianum y le da un nuevo énfasis ante situaciones que marcarán en mayor o menor medida la trayectoria de los Estados

${ }^{67}$ Ibíd.

${ }^{68}$ Pío X, San, Alocución consistorial "Primum vos", 9 de noviembre de 1903. ASS., 36 (Roma, 1903-1904), pp. 193-198. Utilizamos la indicación de página de la colección Doctrina pontificia, II: Documentos políticos (José Luis Gutiérrez García, Madrid, BAC, 1958), pp. 106-111.

${ }^{69}$ Pío X, San, Primum vos, cit. (n. 68), p. 110. "Como defensores de la verdad y de la ley cristiana, es misión obligatoria nuestra: iluminar y establecer las nociones fundamentales del orden natural y del orden revelado, que están hoy oscurecidasy borradas por todas partes [...]; dirigir a todos los hombres [...] también a los que gobiernan [...] en la vida privada y en la vida puiblica, también en las cuestiones sociales y en la politica, según las normas reguladoras de la verdadera moral".

${ }^{70} \mathrm{Ibíd}$.

${ }^{71}$ Ibíd., p. 111.

${ }^{72}$ Pío X, San, Encíclica "Iucunda sane", 12 de marzo de 1904. ASS., 36 (Roma, 19031904), pp. 513-529. Utilizamos la numeración de la versión digital de la Librería Editrice Vaticana, 19.

${ }^{73}$ Ibíd., 20.

${ }^{74}$ Ibíd., 16, 19, 21. El pontífice no exime de responsabilidad a los jerarcas de la Iglesia que prefieren el acomodo a la lucha, cit. (n. 72), 22. 
occidentales durante el siglo XX: la culminación y consolidación del laicismo, y la imposición del democratismo como modelo político de emancipación. Es lo que revisamos a continuación.

\section{El problema del laicismo}

El 29 de julio de 1904 el gobierno de la III República Francesa rompe unilateralmente las relaciones diplomáticas con la Santa Sede ${ }^{75}$. Es un hecho que facilita la separación entre la Iglesia y el Estado, decretada por el Congreso el 9 de diciembre de 1905, a instancias del presidente del Consejo de Ministros Maurice Rouvier (1905-1906), sucesor y seguidor de las políticas de Émile Combes (1902-1905).

Con la separación llega a su clímax la política de laicización desarrollada durante veinticinco años por la cúpula de la república francesa. San Pío X, dentro de un amplísimo cuadro de pronunciamientos contra el laicismo ${ }^{76}$, publica la encíclica Vehementer nos en la que, más allá de la apreciación de los hechos contingentes que la motivan, define la doctrina católica sobre la materia ${ }^{77}$.

a) ¿liberar al género humano de las cadenas del cielo? Descripción y condena global al laicismo

Marcel Gauchet describe el hondo significado que tuvo para la modernidad axiológica la separación francesa de la Iglesia y el Estado. Fue el triunfo, en el "terreno metafísico", de la a u to n o mía contra la he te ro n o mía. La reivindicación final de la emancipación moderna que para decidir colectivamente su destino había de "liberar al género humano de las cadenas del Cielo"78.

\footnotetext{
${ }^{75}$ Sobre la ruptura de relaciones diplomáticas, San Pío X rechazó la acusación de violación del concordato por parte de la Iglesia. Pío X, San, Alocución consistorial, 14 de noviembre de 1904. ASS., 37 (1904-1905), pp. 301-309. También la exposición de la Secretaría de Estado sobre la materia. ASS., 37 (1904-1905), pp. 36-43.

${ }^{76}$ Puede verse la exposición de la Secretaría de Estado con ocasión de la aprobación de la ley (ASS., 38 (1905-1906), Suppl. pp. 1-273); las alocuciones consistoriales del 19 de marzo de 1904 (ASS., 36 (1903-1904), pp. 544-547), del 27 de marzo de 1905 (ASS., 37 (1904-1905), pp. 559-561), del 21 de febrero de 1906 (ASS., 39 (1906), pp. 3033), y del 15 de abril de 1907 (ASS., 40 (1907), pp. 259-261); la carta de San Pío X al cardenal Richard del 4 de octubre de 1905 (ASS., 38 (1905-1906), pp. 193-194); la encíclica Gravissimo officci, 10 de agosto de 1906 (ASS., 39 (1906), pp. 385-390), en la que se ordena regular el culto católico y se prohíben las asociaciones de culto establecidas por la ley de separación; la encíclica Une fois encoré, 6 de enero de 1907 (ASS., 40 (1907), pp. 3-11), sobre la persecución al catolicismo. También es útil la respuesta del episcopado francés a la encíclica Vehementer Nos, en ASS., 39 (1906), pp. 443-448.

${ }^{77}$ Pío X, San, Encíclica "Vehementer nos", 11 de febrero de 1906. ASS., 39 (1906), pp. 3-16. Utilizamos la numeración de la versión digital de la Librería Editrice Vaticana.

${ }^{78}$ GaUCHet, Marcel, La religión en la democracia. El camino del laicismo (Madrid, Ed. Complutense, 2003), pp. 64-67.
} 
San Pío X describe los jalones del proceso $^{79}$.

Se puede observar el carácter paradigmático del modelo francés, pues en lo fundamental las medidas que el pontífice enuncia fueron adoptadas después, de manera gradual, por casi todos los Estados occidentales durante el siglo XX, de un modo ostensible y represivo, o de forma pactada y amigable. A efectos de sus resultados últimos, poco importa si se trata de laicismo o laicidad. El proceso culmina necesariamente con la separación oficial entre la Iglesia y el Estado.

\section{b) el régimen de separación como principio constitucional de los Estados modernos}

Vehementer nos se centra en la separación de la Iglesia y del Estado como principio de organización política. Precisamos a continuación sus tesis: i) la separación entre la Iglesia y el Estado, en sí mismo considerada, merece el calificativo de perniciosa ${ }^{80}$; ii) son cinco los motivos que justifican esta apreciación: a) el régimen de separación es una injuria a Dios (magnam infert iniuriam Deo). Para la sociedad política es obligatorio no solo el culto privado, sino también el culto público (proptereaque non privatim tantummodo colatur necesse est, sed etiam publice $)^{81}$; b) el régimen de separación niega el orden sobrenatural, con lo que limita la acción de Estado a la sola prosperidad pública de la vida terrena, despreocupándose completamente del fin último del hombre ${ }^{82}$; c) el régimen de

${ }^{79}$ Pío X, San, Vehementer nos, cit. (n. 77), 1. Las distintas instituciones y costumbres sociales se van secularizando a paso forzado: el matrimonio, los hospitales y las escuelas, los seminarios, las congregaciones religiosas, las oraciones públicas en la apertura de los tribunales y al comienzo de las sesiones parlamentarias; las tradicionales señales de duelo, en el día de Vienes Santo, a bordo de los buques de guerra; el juramento judicial; los emblemas religiosos, que son quitados de los tribunales, las escuelas y los establecimientos públicos. Podemos identificar algunas normas legales: ley de educación laica obligatoria en la enseñanza primaria pública (28 marzo de 1882); ley de divorcio (27 julio de 1884); ley de supresión de las oraciones públicas al comenzar los periodos parlamentarios (14 agosto de 1884); ley contra el patrimonio de las órdenes y congregaciones religiosas (29 diciembre de 1884); ley de exclusión de las congregaciones e institutos religiosos de la enseñanza pública (30 octubre de 1886 ); ley del servicio militar obligatorio a los clérigos (15 julio de 1889); ley de exclusión de las órdenes y congregaciones religiosas del derecho común (1 julio de 1901); ley de supresión de los institutos religiosos dedicados a la enseñanza (17 julio de 1904).

${ }^{80}$ Pío X, San, Vehementer nos, cit. (n. 77), 3.

${ }^{81}$ Ibíd. El carácter de i n j u r i a, es decir, de o f e n s a, de "agravio inferido a Dios", es consecuencia inmediata del deseo de independencia anejo al régimen de separación. La relación p o s i t i a o n e g a t i v a que el Estado laico adopte en su interior ante el fenómeno religioso es, desde este ángulo, algo s e c u n d a r i o. Lo relevante es que una sociedad política separada formalmente de la religión, específicamente de la religión católica, comete constitutivamente una injuria contra Dios al no reconocer su nombre y su imperio en las instituciones temporales.

${ }^{82}$ Ibíd. En el régimen de separación va envuelta la negación de un principio de máxima importancia para la doctrina católica: la unidad de la naturaleza humana llamada por Dios a un fin sobrenatural. El Estado debe necesariamente favorecer ese fin y en todo lo posible (ita verum est 
separación niega el orden natural, que exige una concordia entre las dos sociedades, la civil y la religiosa ${ }^{83}$; d) el régimen de separación causa gran daño a la sociedad política (maximum importat ipsi societati civili detrimentum), pues esta no logra estabilidad si desprecia la religión, fundamento último de legitimidad del orden moral y jurídico ${ }^{84}$; e) el régimen de separación ha sido reiteradamente condenado por el magisterio pontificio, pues conduce al agnosticismo de Estado, impelido a obrar como si Dios no existiera ${ }^{85}$.

c) el régimen de separación, como principio constitucional que afecta a Francia

El régimen de separación puede considerarse no solo en sí mismo, como principio de organización constitucional de cualquier sociedad política. También es susceptible de ser analizado en cuanto afecta a una nación determinada, habida cuenta de todas sus circunstancias históricas. Es lo que emprende San Pío X al detallar la gravedad de la decisión adoptada por el Estado francés:i) la decisión de la república viola la vocación histórica de Francia, unida genéticamente a la fe católica ${ }^{86}$; ii) la decisión unilateral de la república viola el derecho concordatario

rempublicam non modo non obesse, sed prodesse oportere). El poder político tiene, en consecuencia, una finalidad sagrada, que aquí el papa formula negativa y positivamente. Negativamente, el Estado no debe impedir la consecución del fin último, vr. gr., violando en algún punto la ley divino-natural. Positivamente, debe colaborar desde el ámbito de lo temporal a su consecución.

${ }^{83}$ Ibíd., "Praetera descriptionem pervertit rerum humanarum a Deo sapientissime constitutam, quae profecto utriusque societatis, religiosae et civilis, concordiam requirit". El texto profundiza un aspecto a menudo olvidado de la cuestión: el régimen de concordia entre el poder político y la Iglesia es el único conforme al orden humano. No se trata propiamente de un i d e a 1 sino de una e x i g e n c i a del orden social visto desde el punto de vista del fin último de todos los hombres. Esta doctrina es apodíctica, siempre que se comparta el presupuesto de que existe una sociedad religiosa con una misión y estructura como la que se atribuye la Iglesia. De esto se deduce que para una mentalidad católica no debería existir duda alguna acerca de cuál es el régimen genuinamente cristiano. De donde la opción por el laicismo es nula, salvo como régimen a tolerar en calidad de mal menor atendida las circunstancias.

${ }^{84}$ Ibíd. La doctrina lleva implícita la noción de que la sociedad política es una comunidad de fines que se ajustan dentro de un bien común de contenido jerárquico. La religión es “ regla y maestra suprema" porque inspira objetivamente las razones absolutas para obrar conforme al derecho y al deber. Su manifestación palpable es la estabilidad delos gobiernos. La afirmación, sin embargo, no parece tener validez para una concepción como la contemporánea donde la sociedad se ha convertido en una agrupación yuxtapuesta de autonomías individuales donde el Estado es el árbitro público de los disensos. Los derechos son individuales y los deberes medios correlativos para asegurar tales derechos. Ello explica quizás el cambio de óptica de la doctrina eclesial a partir del Concilio Vaticano II, que favorece la libertad religiosa como un derecho fundado en la dignidad del hombre, con cierta desconexión hacia el bien común espiritual de las naciones cristianas. De cualquier forma, si esto es así, la encíclica daría razón a quienes hoy prefieren hablar no de sociedad sino de d i s o c i e d a d en expansión. DE Corte, Marcel, De la societé à la térmitière par la dissociété, en L'Ordre Français, 180 y 181 (1974), pp. 5-29. Resulta del todo imposible reconoceruna sociedad genuinadonde no hay comunidad, bien común, o ley trascendente, o donde los deberes primarios son meros contrapuntos correlativos a los derechos subjetivos.

${ }^{85}$ Pío X, San, Vehementer nos, cit. (n. 77), 3, con cita a Immortale Dei de León XIII.

${ }^{86}$ Pío X, San, Vehementer nos, cit. (n. 77), 4. 
y el derecho internacional ${ }^{87}$; iii) la decisión de la república es contraria a la justicia natural y positiva. En este punto la encíclica denota que el laicismo francés es un laicismo de combate: no se trata sólo de prescindir de la religión católica sino de privarla incluso de los derechos que los individuos y asociaciones gozan por derecho común. En concreto, la ley de separación entre la Iglesia y el Estado lleva aneja una serie de medidas lesivas a los derechos de la iglesia ${ }^{88}$; iv) la decisión de la república es contraria al derecho divino-eclesiástico. Al establecer la tutela estatal en la administración del culto, contradice la constitución jerárquica de la iglesia ${ }^{89}$; v) la decisión de la república desconoce la libertas Ecclesiae en un Estado que dice consagrar la libertad moderna de $\operatorname{cultos}^{90}$.

En suma, recapitulando lo establecido en b) y c), San Pío X rechaza el régimen de separación, por principios doctrinales de valor permanente y por motivos históricos ${ }^{91}$.

\section{d) las puntualizaciones subsecuentes}

En Gravissimo offichii munere defungimur se explicita cuál es el criterio que justifica la tolerancia hacia un régimen de separación. Cuando la separación garantiza libertad plena a la Iglesia, se la puede o se la debe tolerar como un mal menor según las circunstancias. Tal es el caso alemán. En cambio, cuando la separación supone la opresión de la Iglesia y hiere injustamente los derechos de la sociedad política cristiana, la lucha activa -dentro de la ley- es inevitable ${ }^{92}$.

Une fois encore denuncia el modo artero en que se aplica la ley francesa de separación. Su objetivo último es descristianizar Francia. El régimen impuesto representa un capítulo más de la lucha moderna contra Dios y lo sobrenatural ${ }^{93}$.

La encíclica Iamdudum in lusitania rechaza el régimen de separación entre la

${ }^{87}$ Ibíd., 5, 6, 11, con referencias a la Revolución Francesa.

${ }^{88}$ Ibíd., 7 y 10 . El derecho de propiedad es el que más ostensiblemente viola el Estado francés al despojar a la Iglesia y a los institutos religiosos, incluso los de enseñanza, del patrimonio que les pertenece por títulos jurídicos válidos, a fin de reducir a la impotencia los medios de acción del catolicismo. El culto católico también se ve afectado, pues la ley entrega la propiedad y administración de los templos católicos a asociaciones laicas, cuyos hilos proyecta manejar en definitiva el Estado. En tales iniciativas, aparece otro título para el rechazo pontificio, atendidas las condiciones de tiempo y de lugar en que se ha impuesto el régimen de separación en Francia: el Estado se está expandiendo en su poder omnímodo al invadir la esfera que corresponde al poder espiritual.

${ }^{89}$ Ibíd., 8.

${ }^{90}$ Ibíd., 9 .

${ }^{91}$ El mismo pontífice hace una recapitulación, invocando la autoridad de Dios, para “condenar y reprobar" el régimen de separación. Ibíd., 13. La fórmula muestra la autoridad magisterial que el documento tiene en la intención de San Pío X. Además, cosa notable para el siglo XX, el papa declara nulos los preceptos de la ley francesa que atentan, del modo indicado, contra los derechos de la Iglesia y de la nación católica.

${ }^{92}$ Pío X, San, Encíclica “Gravissimo offichii munere defungimur”, 10 de agosto de 1906. ASS., 39 (1906), pp. 385-390.

${ }^{93}$ Pío X, San, Encíclica "Une fois encore”, 6 de enero de 1907. ASS 40., (1907), pp. 3-11. 
Iglesia y el Estado impuesto por la república portuguesa. En lo sustancial, San Pío X reitera que no sólo los individuos sino también los pueblos y las sociedades políticas tienen la obligación de rendir culto a Dios. Máxime en naciones católicas, como es el caso de Portugal ${ }^{94}$. En Gravissimum apostolici, el pontífice insiste ante el consistorio de cardenales en que régimen de separación es "contrario a los derechos de Dios y de la Iglesia". No sólo los individuos sino también las sociedades políticas tienen deberes hacia el verdadero Dios ${ }^{95}$.

Complementariamente, Singulari quadam defiende el principio de confesionalidad de los cuerpos asociativos, advirtiendo acerca de los peligros de las asociaciones interconfesionales o laicas ${ }^{96}$. En $C^{\prime}$ est avec une bien douce dedicada a la memoria de Louis Veuillot, San Pío X destaca la lucha de este escritor contra-revolucionario frente al laicismo y las libertades modernas, así como su defensa de la comunidad política fundada en la realeza social de Jesucristo ${ }^{97}$.

La carta Le Saint Père declara que los principios del magisterio pontificio que regulan las relaciones entre la Iglesia y la sociedad política son inmutables, en la medida en que derivan del derecho divino. Lo que, por lo demás, se deduce directamente de las palabras de San Pío X ${ }^{98}$.

\section{e) Estado laico y libertades modernas}

El papa Sarto precisa que el Estado moderno restringe la libertad de la Iglesia situándola en el período anterior a Constantino, como si la milenaria veneración del poder político a la verdad cristiana careciera de fundamento o de entidad. El laicismo es una inversión de órdenes pues al desvincular la sociedad política de la fe, termina sometiendo el orden divino al estatal ${ }^{99}$. El Estado moderno se atribuye la capacidad de legislar en el ámbito espiritual precisamente porque ha

${ }^{94}$ Pío X, San, Encíclica "Iamdudum in lusitania", 24 de mayo de 1911. AAS., 3 (1911), pp. 217-224. La Encíclica termina con una condenación solemne de la ley de separación, aludiendo no sólo a sus circunstancias históricas sino también a sus principios doctrinales, de modo análogo a Vehementer nos. Siguiendo ese parámetro, también declara la nulidad de los preceptos de la ley.

${ }^{95}$ Pío X, San, Alocución consistorial “Gravissimum apostolici”, 21 de febrero de 1906. ASS., 39 (1906), pp. 30-33.

${ }^{96}$ Pío X, San, Encíclica "Singulari quadam", 24 de septiembre de 1912. AAS., 4 (1912), pp. 657-662.

${ }^{97}$ Pío X, San, Carta "C'est avec une bien douce”, 22 de octubre de 1913. AAS., 5 (1913), pp. 513-515.

${ }^{98}$ Merry del Val, Rafael, Carta “Le Saint Père”, 14 de octubre de 1913. AAS., 5 (1913), pp. 558-560. Precisa además que son errores correlativos la tesis de la separación entre la Iglesia y el Estado; la afirmación de que ambos poderes tienen que estar unidos sólo por coordinación y no, en lo que cabe, por subordinación; y la sentencia que niega que la Iglesia tenga una potestad espiritual indirecta en lo temporal.

${ }^{99}$ Pío X, San, Discurso "La vostra presenza" a los peregrinos llegados a Roma con motivo del XVI centenario del edicto de Constantino. AAS., 5 (1913), pp.147-151. 
reducido a la religión comunitaria a una asociación de derecho común sometida a sus regulaciones ${ }^{100}$.

En el discurso a los peregrinos de Milán, el pontífice describe cómo con una mano el Estado moderno consagra las libertades individuales, y con la otra, ahoga la libertad de la Iglesia y asfixia la moral católica y la fe ambiental ${ }^{101}$.

$\mathrm{Ni}$ el laicismo ni las libertades modernas son neutras. Ante Dios no hay neutralidad. Son parte de una lucha profundamente antiteísta, que tiene su faceta política y jurídica.

\section{El problema de la democracia moderna}

Notre charge apostolique formula un juicio global de la tendencia democratista de la modernidad política. Lo hace a propósito de la evolución del movimiento católico francés Le Sillon. Es lo que analizamos a continuación.

\section{a) la unidad de las doctrinas fundamentales de la modernidad politica}

Notre charge apostolique enlaza "las doctrinas de los llamados filósofos del siglo XVIII, de la Revolución y del liberalismo, tantas veces condenadas"102. Da por supuesto el conocimiento de su desarrollo, y, en parte, le analiza en el cuerpo de la encíclica cuando se refiere a los diversos tipos de emancipación moderna. Las tesis principales pueden formularse del siguiente modo: i) las doctrinas fundamentales de la modernidad política no reconocen el orden natural y pretenden edificar la ciudad nueva negando las tres bases que componen la civilización cristiana ${ }^{103}$. El proyecto moderno se caracteriza por ser utópico, rebelde a Dios e impío; ii) el Estado de lucha es recíproco: el proyecto moderno pretende d e c o n s t r u i r la civilización cristiana, y con ella, la ciudad católica; mientras la Iglesia tiene como misión, ante tal ejecutoria, contraatacar promoviendo el ideal de la verdadera civilización. Es una promoción que debe redundar, cuando las condiciones la hagan posible, en una i n s t a u r a c i ó n y una r e s t a u r a c i ó $\mathrm{n}$ de la civilización que la revolución moderna ha

${ }^{100}$ Pío X, San, Carta al Dr. Josep Torras i Bages, obispo de Vich. AAS., 3 (1911), pp. 232-233. Se enfoca la cuestión de la soberanía absoluta del Estado moderno, oponiéndole los límites de la ley divino-natural. También, Pío X, San, Alocución a los peregrinos franceses, 13 de noviembre de 1909. AAS., 1 (1909) pp. 789-791. Se declara que el poder del Estado se vuelve absoluto, árbitro de la religión, oráculo supremo de la doctrina y el derecho.

${ }^{101}$ Pío X, San, Discurso a los peregrinos de la Diócesis de Milán, 3 de abril de 1913. En Valuet, Basile, La Liberté religieuse et la tradition catholique (Le Barroux, Abbaye SainteMadeleine, 1998, II-A), pp. 1143-1144.

${ }^{102}$ Pío X, San, Notre charge apostolique, cit. (n. 64), 1.

${ }^{103}$ Ibíd., 10. "Esto es, sin embargo, lo que ellos quieren hacer de la sociedad humana; su sueño consiste en cambiar sus cimientos naturales y tradicionales (ses bases naturelles et traditionnelles) y en prometer una ciudad futura edificada sobre otros principios (sur d'autres principes) que se atreven a declarar más fecundos, más beneficiosos que aquellos sobre los que descansa la actual sociedad cristiana". Sobre las tres bases aludidas, véase nota 62 . 
destruido. Instaurar (instaurer) es establecer algo de acuerdo con las nuevas condiciones históricas. Restaurar (restaurer) es vincularse al pasado histórico de la cristiandad a través de la virtud colectiva de la pietas. Esta restauración es contrapuesta al democratismo y, más ampliamente, al espíritu revolucionario de la modernidad política ${ }^{104}$.

\section{b) los dogmas democratistas}

La tendencia democratista se expresa en un conjunto de principios fundamentales. Se les puede formular del modo que sigue: i) el orden temporal no necesita someterse a la autoridad espiritual en las decisiones morales fundamentales $^{105}$; ii) el dogma de la dignidad humana como autonomía, base de la triple emancipación, permite fundar el colectivo político en el principio de inmanencia ${ }^{106}$; iii) el lema de la revolución francesa "Libertad, igualdad y fraternidad" constituye una ruptura con el principio de autoridad y de jerarquía, reflejo en la sociedad temporal de la trascendencia divina y del orden de la creación: a) la libertad revolucionaria, canalizada en el dogma de la soberanía popular, pretende la plena autonomía del orden político respecto del origen divino del poder, del principio de autoridad y de bien común ${ }^{107}$; b) la igualdad, entendida como un principio de destrucción de las legítimas desigualdades sociales, es, para la revolución, una

${ }^{104}$ Sobre este último punto, particularmente Pío X, San, Notre charge apostolique, cit. (n. 64), 44. La alusión a les organismes brisés par la Révolution es reveladora de la importancia de la tradición como categoría católico-política opuesta a la R e v o l u c i ó n y a la I n n o v a c i ó n anti-natural. R e s t a u r a c i ó n y t r a d i c i ó n son términos consonantes. Los organismos rotos por la Revolución, partiendo por la familia tradicional, eran precisamente los que daban vida a la sociedad y constituían zonas de libertades y contrapoderes que el poder político prerevolucionario, a diferencia del Estado, no podía invadir. La encíclica da con ello una clave de significación concreta de la orientación que debe tomar la ciudad católica en el futuro, vinculada siempre a una tradición que, sin embargo, la Revolución ha quebrado.

${ }^{105}$ Pío X, San, Notre charge apostolique, cit. (n. 64), 7 y 8. La tesis es lógica si se acepta que la Iglesia es depositaria de la verdad divina y recibió autoridad magisterial del mismo Cristo para transmitirla e interpretarla. En la tesis no se incluye el comportamiento moral de los pastores, que puede ser ocasión de escándalo, ni la enseñanza de doctrinas nuevas que no se vinculan al depósito de la fe, ni la imposición de una sentencia en materias que el magisterio pontificio no ha definido, o en las que no es competente.

${ }^{106}$ Ibíd., 13-19, 25. La L i b e r t a d e I g u a l d a d (así, en abstracto) son los ideales míticos de la democracia moderna y permiten canalizar la emancipación política, económica e intelectual, rumbo a la prometida autonomía individual y social. La dignidad humana se entiende, en un sentido de raíz kantiana, como una libertad de autonomía en todos los órdenes. De la dignidad humana se deduce la autonomía y de la autonomía se deriva la lucha por la emancipación (émancipation). En rigor, la sola afirmación de la dignidad humana autónoma como principio del orden político basta para sumergirlo, sin vías de escape, en la lógica de la inmanencia. A partir de tal dignidad es el hombre el que debe construir desde su propia subjetividad el espacio político y económico y la verdad social. Es la partida de confirmación del Estado máquina o artificio, de la sociedad convertida en masa aglutinante de individuos, de la propaganda en sustitución del orden natural, y de la urdidura del poder total, resultados reales de la Modernidad política a los que tendrán que hacer frente Pío XI y Pío XII.

${ }^{107}$ Ibíd., 21 y 22. 
exigencia de justicia. La modernidad política se apoya en esa veta para disolver lo más posible las genuinas diferencias, rumbo a la uniformización y masificación del ser humano. Este principio, contrario al orden natural, es el fundamento de la democracia actual, que no pretende ser una forma de gobierno, sino el fundamento de todo gobierno ${ }^{108}$; c) la fraternidad revolucionaria, como nuevo lazo de unión moral, es un vehículo para propagar el indiferentismo religioso y moral al interior de las antiguas sociedades cristianas ${ }^{109}$; iv) las libertades modernas se oponen al principio vital católico ${ }^{110}$; v) no se puede conciliar el Evangelio con las ideas políticas de la revolución ${ }^{111}$.

Con lo precedente, queda claro el significado antimoderno del corpus politicum pianum. Es de advertir, que contiene principios fundamentales, de tal manera que su doctrina sustancial no puede ser reducida a mero consejos prudenciales. Los principios que establece no son solo relativos a determinadas circunstancias históricas, pasadas las cuales, ya no rigen. Son perennes y no se disuelven en la relatividad de una contingencia ya superada.

\section{Conclusión}

1. El corpus politicum pianum se inserta dentro de la amplia mirada antimoderna del pontífice, envés de su designio positivo de Instaurare omnia in Christo.

2. Existen, sin embargo, otras líneas interpretativas. Unos concuerdan con la centralidad del enfoque antimoderno, pero lo valoran en términos negativos. Otros afirman que lo esencial no se encuentra ahí, sino en la amplia labor reformadora del pontífice, que le hace mirar hacia el futuro, en un sentido precursor de la apertura de la iglesia al mundo moderno. Desde este ángulo, los pronunciamientos políticos de San Pío X se encontrarían superados, como la lucha contra

${ }^{108}$ Ibíd., 23, 28. De ahí la defensa exclusivista de la democracia. Ibíd, 31. En otro lugar, se muestra la profunda consonancia de principios político-sociales entre San Pío X y León XIII. Entre los cuales figura el principio jerárquico plasmado en una concepción de la sociedad política que contradice al colectivo igualitario de la democracia moderna. Pío X, San, Fin dalla prima nostra encíclica, 18 de diciembre de 1904. ASS., 36 (1903-1904), pp. 339-345.

${ }^{109}$ Pío X, San, Notre charge apostolique, cit. (n. 64), 23. Para el pontífice la retórica de la tolerancia -al uso de la Ilustración- es una pieza de la fraternidad revolucionaria. La fraternidad y la tolerancia (dogmática y moral) vienen a sustituir en la nueva ciudad política al amor a Jesucristo, quien pasa a ser un motivo de división entre los hombres.

${ }^{110} \mathrm{El}$ catolicismo es el principio vital que anima la sociedad cristiana. "No hay verdadera civilización sin la civilización moral, y no hay verdadera civilización moral sin la verdadera religión”, puntualiza el pontífice. Pío X, San, Notre charge apostolique, cit. (n. 64), 33.

${ }^{111}$ San Pío X precisa que el Evangelio predica una sociedad opuesta a los ideales revolucionarios de la democracia moderna. En ella, la emancipación de la Ley sustituye a la idea cristiana como reguladora del orden político. Por detrás de sus vagos ideales humanitarios yace la desnuda exaltación humana curvada sobre sí misma. Mientras la fe de Cristo rescata a los hombres del pecado, la fe democrática promete rescatarles de las trabas que les hace desiguales y no emancipados. Se trata de una nueva religión, la religión democrática de la humanidad. Pío X, San, Notre charge apostolique, cit. (n. 64). 
el modernismo religioso, que se reduce, en todo caso, a un fenómeno de inicios del siglo XX, sin vigencia para nuestros días.

3. Hay un equívoco en estas posturas. El modernismo religioso responde a una cosmovisión, a unos principios filosóficos que se proyectan a la dimensión política y social. Esa cosmovisión, esos principios, constituyen la modernidad axiológica o teorética, que se distingue de la modernidad cronológica. A su modo, fueron explicitados por San Pío X y es lo que da unidad de significado a su corpus politicum.

4. En esta línea, el papa Sarto hace un pronóstico y un diagnóstico de la modernidad axiológica. Le considera un proyecto de destrucción del orden natural y cristiano, que lleva a la apostasía de las naciones y a la demolición de la civilización cristiana, cuyos componentes esenciales describe.

5. La dimensión política de la civilización cristiana es la comunidad política religiosa, que en el siglo XIX se manifiesta en el Estado confesional. Su expresión jurídica es el derecho público cristiano. Instituciones todas que la modernidad axiológica pretende arrumbar.

6. A la época de San Pío X, el espíritu moderno despliega los proyectos de autonomía inmanentista por dos vías centrales: el laicismo y el democratismo, cuya vigencia no ha hecho más que crecer hasta nuestros días.

7. El laicismo se consolida con el régimen de separación oficial IglesiaEstado, elevado a principio constitucional del derecho público moderno. El corpus politicum pianum da al menos diez razones (cinco teóricas, cinco históricas) para rechazar esta solución. Advierte que con ello el poder moderno se convierte en absoluto. Las consecuencias colaterales son conocidas: dominio simbólico del Estado, positivismo, intervencionismo jurídico, uniformización general, masificación universal.

8. La tendencia democratista se formaliza en un conjunto de principios fundamentales. Todos ellos se expresan en categorías íntimamente relacionadas: Libertad, Igualdad, Fraternidad (en abstracto, con mayúsculas), soberanía popular, emancipación, dignidad humana. A primera vista, parecieran expresar ideas positivas. Pero en el trasfondo yace la mano negra de la revolución, por donde se pretende fundar el colectivo político en el principio de inmanencia. Se liquidan las libertades asociativas históricas, se fuerza a la sociedad a expulsar el bien común como referente y se le condena a destruir todo lo estable.

9. El corpus politicum pianum es una proyección del corpus politicum leonianum. Contiene principios fundamentales, de tal manera que su doctrina sustancial no puede ser reducida a mero consejos prudenciales. Los principios que establece no son solo relativos a determinadas circunstancias históricas, pasadas las cuales, ya no rigen. Son perennes y no se disuelven en la relatividad de una contingencia ya superada. 


\section{BiBLIOGRAFÍA}

Documentos pontificios

Benedicto XV, Ad Beatissimi Apostolorum, 1 de noviembre de 1914. AAS., 6 (1914), pp. 565-581.

Merry del Val, Rafael, Carta "Le Saint Père", 14 de octubre de 1913. AAS., 5 (1913), pp. 558-560.

Pío X, San, Encíclica "Ad diem illud laetissimum", 2 de febrero de 1904. ASS., 36 (1903-1904), pp. 449-462.

- Alocución peregrinos franceses, 13 de noviembre de 1909. AAS., 1 (1909) pp. 789-791.

- Discurso peregrinos de Milán, 3 de abril de 1913, en Valuet, Basile, La liberté religieuse et la tradition catholique (Le Barroux, Abbaye Sainte-Madeleine, 1998, II-A), pp. 1143-1144.

- Carta al Cardenal Richard, 4 de octubre de 1905. ASS., 38 (1905-1906), pp. 193-194.

- Carta al Dr. Josep Torras i Bages, obispo de Vich. AAS., 3 (1911), pp. 232-233.

- Carta "C'est avec une bien douce", 22 de octubre de 1913. AAS., 5 (1913), pp. 513-515.

—Encíclica "Communium rerum", 21 de abril de 1909. AAS., 1 (1909), pp. 333-388.

- Alocución consistorial, 19 de marzo de 1904. ASS., 36 (1903-1904), pp. 544-547.

- Alocución consistorial, 14 de noviembre de 1904. ASS., 37 (1904-1905), pp.301-309.

- Alocución consistorial, 27 de marzo de 1905. ASS., 37 (1904-1905), pp. 559-561.

- Alocución consistorial, 21 de febrero de 1906. ASS., 39 (1906), pp. 30-33.

- Alocución consistorial, 15 de abril de 1907. ASS., 40 (1907), pp. 259-261.

- Motu proprio "Doctoris angelici", 29 de junio de 1914. AAS., 6 (1914), pp. 336-341.

- Fin dalla prima nostra encíclica, 18 de diciembre de 1904. ASS., 36 (1903-1904), pp. 339-345.

- Encíclica "Iamdudum in Lusitania", 24 de mayo de 1911. AAS., 3 (1911), pp. 217-224.

- Encíclica "Il fermo propósito", 11 de junio de 1905. ASS., 37 (1904-1905), pp. 741-767.

— Alocución "Il grave dolore", 28 de mayo de 1914. AAS., 6 (1914), pp. 260-263.

- Encíclica "Iucunda sane", 12 de marzo de 1904. ASS., 36 (1903-1904), pp. 515-529.

- Alocución "Gravissimum apostolici", 21 de febrero de 1906. ASS., 39 (1906), pp. 30-33.

—Encíclica "Gravissimo officci", 10 de agosto de 1906. ASS., 39 (1906), pp. 385-390.

- Discurso "La vostra presenza". AAS., 5 (1913), pp. 147-151.

- Decreto del Santo Oficio "Lamentabili", 3 de julio de 1907. ASS., 40 (1907), pp. 470-478.

- Encíclica "Notre charge apostolique", 25 agosto de 1910. AAS., 2 (1910), pp. 607-633.

— Encíclica "Pascendi Dominici gregis", 8 de septiembre de 1907. ASS., 40 (1907), pp. 593-650. 
- Alocución "Primum vos", 9 de noviembre de 1903. ASS., 36 (1903-1904), pp. 193-198.

- Motu proprio "Sacrorum antistitum", 1 de diciembre de 1910. AAS., 2 (1910), pp. 655-680.

- Encíclica "Singulari quadam", 24 de septiembre de 1912. AAS., 4 (1912), pp. 657-662.

- Encíclica "Supremi apostolatus", 4 de octubre de 1903. ASS., 36 (1903-1904), pp. 129-139.

- Encíclica "Une fois encore", 6 de enero de 1907. ASS., 40 (1907), pp. 3-11.

- Encíclica "Vehementer nos", 11 de febrero de 1906. ASS., 39 (1906), pp. 3-16.

—Encíclica "Ubi Arcano", 23 de diciembre de 1922. AAS., 14 (1922), pp. 673-700.

Pío XII, Discorsi e radiomessaggi di sua Santità Pio XII, XIII Tredicesimo anno di pontificato (2 marzo 1951-1 marzo 1952) (Città del Vaticano, Tipografía Poliglotta Vaticana, 1953), pp. 127-136.

- Discorsi e radiomessaggi di sua Santità Pio XII, XVI, Sedicesimo anno di pontificato (2 marzo 1954-1 marzo 1955) (Città del Vaticano, Tipografía Poliglotta vaticana, 1956), pp. 32-37.

Secretaría de Estado, Exposición documentada. ASS., 37 (1904-1905), pp. 36-43.

— Exposición documentada. ASS., 38 (1905-1906), Suppl. pp. 1-273.

Bibliografía general

Alférez, Gabriel, El mal menor en política. Historia y aplicaciones actuales, en Verbo, 269-270 (Madrid, 1988), pp. 1237-1258.

Alvear Téllez, Julio, La crítica al discurso de los derechos humanos (Valencia, Tirant lo Blanch, 2018).

- La libertad moderna de conciencia y de religión. El problema de su fundamento (Madrid-Barcelona, Marcial Pons, 2013).

Arnold, Claus y Vian, Giovanni (cur.), La condanna del modernismo. Documenti, interpretazioni, conseguenze (Roma, Viella, 2010).

Ayuso, Miguel, La devastación modernista y su denuncia profética, en Verbo, 455-456 (Madrid, 2007), pp. 449-469.

Bedeschi, Lorenzo, Il modernismo italiano. Voci e volti (Milano, Edizioni San Paolo, 1995).

CABello, Emmanuel, La renovación de la vida cristiana, en Anuario de Historia de la Iglesia, 6 (Pamplona, 1997), pp. 45-60.

Canals Vidal, Francisco, Cristianismo y revolución (2a ed., Madrid, Speiro, 1986).

Castellano, Danilo, El modernismo político-social, en Verbo, 455-456 (Madrid, 2007), pp. 421-430.

- L'ordine della politica. Saggi sul fondamento e sulle forme del político (Napoli-Roma, Edizioni Scientifiche Italiane, 1997).

- La politica tra Scilla e Cariddi (Napoli-Roma, Edizioni Scientifiche Italiane, 2010).

De Christiana Republica (Napoli-Roma, Edizioni Scientifiche Italiane, 2004).

- La tradición política católica frente a las ideologías revolucionarias (Madrid, Consejo de Estudios Hispánicos, 2019).

Cattaneo, Arturo (cur.), L'eredità giuridica di San Pio X (Venezia, Marcianum Press, 2006).

CorrêA de Oliveira, Plinio, Revolución y contra-revolución (Santiago, Ed. Apóstol Santiago, 1992). 
Croce, Benedetto, Storia d'Europa nel secolo decimonono (Bari, Laterza, 1938).

Dal-Gal, Geronimo, San Pío X. El papa santo (Madrid, Palabra, 1954).

Daniel-Rops, L'église des revolutions. Un combat pour Dieu (Paris, Fayard, 1963).

De CORTE, Marcel, De la societé à la térmitière par la dissociété, en L'Ordre Français, 180/1 (1974), pp. 5-29.

De Ruschi, Luis María, Vigencia de la noción de Iglesia como sociedad jurídicamente perfecta y su anclaje en el derecho natural, en Verbo, 523-524 (Madrid, 2014), pp. 239-261.

Dieguez, Alejandro, La nuova documentazione dell'Archivio Vaticano per una migliore comprensione della figura e opera di Giuseppe Sarto-Pio X, en Anuario de Historia de la Iglesia, 23 (Pamplona, 2014), pp. 169-185.

Dumont, Bernard, El modernismo después de la encíclica "Pascendi", en Verbo, 455-456 (Madrid, 2007), pp.431-448.

Ferrer, Melchor, Historia del tradicionalismo español (Sevilla, Editorial Católica Española, 1959), XVIII, I.

EPISCOPADO FRANCÉS, Respuesta sobre la encíclica “Vehementer Nos", en Acta Sanctae Sedis, 39 (Roma, 1906), pp. 443-448.

FABRO, Cornelio, L'avventura della teologia progresista (Milano, Ruscone, 1974).

- Introduzione all'ateismo moderno (Roma, Studium, 1969).

Fantappì, Carlo, Chiesa romana e modernità giuridica (Milano, Giuffrè, 2008).

GAMBRA, Andrés, Los católicos y la democracia. Génesis histórica de la democracia cristiana, en Los católicos y la acción política (Madrid, Speiro, 1982), pp. 11-284.

Gambra, José Miguel, El modernismo filosófico, en Verbo, 455-456 (Madrid, 2007), pp. 395-420.

Gambra, Rafael, Eso que llaman Estado (Madrid, Montejurra, 1958).

- Historia sencilla de la filosofía (24a ed., Madrid, Rialp, 1999).

García Ortí, Vicente, San Pío X, los jesuitas y los integristas españoles, en Archivum Historiae Pontificiae, 27 (Roma, 1989), pp. 249-355.

GAUCHET, Marcel, La religión en la democracia. El camino del laicismo (Madrid, Ed. Complutense, 2003).

GonzÁlez-Quevedo S.J., Jesús, Por la instauración de un orden cristiano, en Verbo, pp. 959-980.

Gramsci, Antonio, Cuadernos de la Cárcel (ed. crítica del Instituto Gramsci, a cargo de valentino Guerratana, México, Ediciones Era), II (1981), V (1999) y VI 6 (2000).

Havard de la Montagne, Robert, Histoire de la démocratie chrétienne de Lamennais à Georges Bidault (París, Amiot et Dumont, 1948).

Illanes, José Luis, Cristianismo, historia, mundo (Pamplona, Eunsa, 1973).

Il PROGRAmMa Del ModernisTi (Turin, Bocca, 1911).

Jedin, Hubert (dir.), Manual de historia de la Iglesia (Barcelona, Herder, 1978), VIII.

La Bella, Gianni (cur.), Pio Xe il suo tempo (Bologna, il Mulino, 2003).

LoIsY, Alfred, Simples réflexions sur le decret du Saint Office "Lamentabili Sane Exitu", et sur l'Encyclique "Pascendi Dominici Gregis" (Ceffond, près Montier-en-Der, Haute-Marne, Chez l'Auteur, 1908).

Madiran, Jean, San Pio X, en Verbo, 529-539 (Madrid, 2014), pp. 731-756.

- En el centenario de "Notre charge apostolique", en Verbo, 491-492 (Madrid, 2011), pp. 15-25.

- Réflexions autour de La Cité Catholique, en Itinéraires, 62 (1962). 
Meinvielle, Julio, De Lamennais à Maritain (Poitiers, Dominique Martin Morin, 2001).

Montalbán, Francisco; Llorca, Bernardino y García Villoslada, Ricardo, Historia de la Iglesia católica (2a ed., Madrid, Biblioteca de Autores Cristianos, 1958), IV. KASPER, Walter, Teología e Iglesia (Barcelona, Herder, 1989).

Ramontin, Silvio (cur.), Le radici venete di San Pio X (Brescia, Morcelliana, 1987).

Robles Muñoz, Cristóbal, El modernismo religioso y su crisis, I: Preliminares (Madrid, ACCI, 2016); II: La condena 1906-1913 (Madrid, ACCI, 2017); III: Después de Pio X (Madrid, ACCI, 2017).

Romanato, Gianpaolo, Pio X: studi e interpretazioni, en Anuario de Historia de la Iglesia, 23 (Pamplona, 2014), pp. 153-167.

- Pio X. Alle origini del cattolicesimo contemporáneo (Torino, Lindau, 2014).

Rops, Daniel, Historia de la Iglesia de Cristo (Madrid-Alcalá, Círculo de Amigos de la Historia, 1971) XII/1.

Salinas Araneda, Carlos, La participación de los obispos del Perú en la codificación del Derecho Canónico de 1917 (Lima, PUCP- Instituto Riva-Agüero, 2012).

SARANYANa, Josep et al., El caminar histórico de la santidad cristiana (Pamplona, Eunsa, 2003).

Sorel Climent, Jorge, El contexto histórico de la encíclica "Pascendi", en Verbo, 455-456 (Madrid, 2007), pp. 375-384.

Spirito, Ugo y Del Noce, Augusto, Tramonto o eclissi dei valori tradizionali? (Milano, Rusconi, 1971).

VACANT, et al., Dictionnaire de théologie catholique (Paris, Librairie Letouzey, 1929), $\mathrm{X} / 2$.

Valverde, Carlos, Génesis, estructura y crisis de la modernidad (Madrid, BAC, 1996).

Vegas Latapié, Eugenio, El modernismo después de la "Pascendi", en Verbo, 65-66 (Madrid, 1968), pp. 351-385.

VIAN, Giovanni, Il modernismo. La Chiesa cattolica in conflitto con la modernità (Roma, Carocci, 2012).

- La riforma della Chiesa per la restaurazione cristiana della società. Le visite apostoliche delle diocesi e dei seminari d'Italia promosse durante il pontificato di Pio X (Roma, Herder, 1998), 2 vols. 